
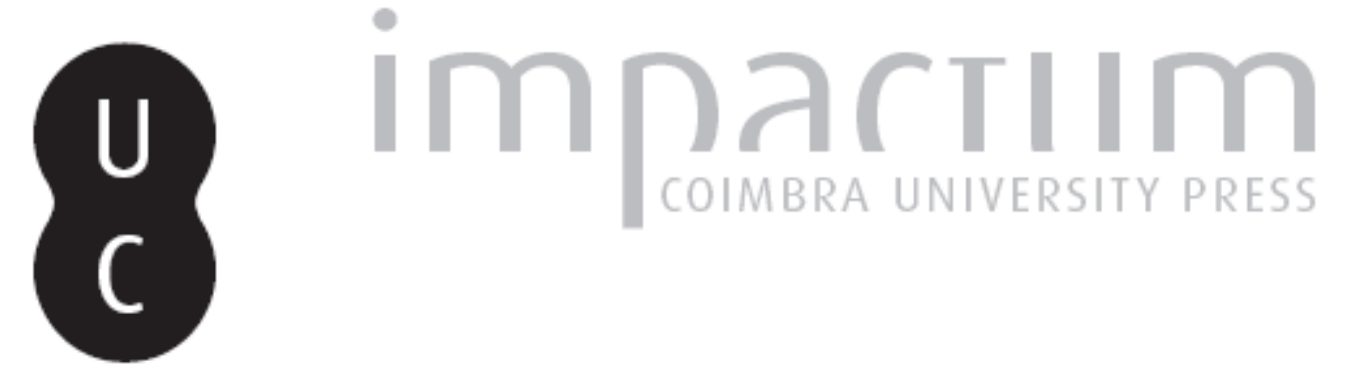

\title{
A ideia geral do "Aconselhamento Filosófico": uma introdução ao tema
}

Autor(es): Menezes, Filipe M.

Publicado por: Faculdade de Letras da Universidade de Coimbra, Instituto de Estudos Filosóficos

URL

persistente:

URI:http://hdl.handle.net/10316.2/29609

DOI:

DOI:http://dx.doi.org/10.14195/0872-0851_39_4

Accessed : $\quad$ 26-Apr-2023 13:59:05

A navegação consulta e descarregamento dos títulos inseridos nas Bibliotecas Digitais UC Digitalis, UC Pombalina e UC Impactum, pressupõem a aceitação plena e sem reservas dos Termos e Condições de Uso destas Bibliotecas Digitais, disponíveis em https://digitalis.uc.pt/pt-pt/termos.

Conforme exposto nos referidos Termos e Condições de Uso, o descarregamento de títulos de acesso restrito requer uma licença válida de autorização devendo o utilizador aceder ao(s) documento(s) a partir de um endereço de IP da instituição detentora da supramencionada licença.

Ao utilizador é apenas permitido o descarregamento para uso pessoal, pelo que o emprego do(s) título(s) descarregado(s) para outro fim, designadamente comercial, carece de autorização do respetivo autor ou editor da obra.

Na medida em que todas as obras da UC Digitalis se encontram protegidas pelo Código do Direito de Autor e Direitos Conexos e demais legislação aplicável, toda a cópia, parcial ou total, deste documento, nos casos em que é legalmente admitida, deverá conter ou fazer-se acompanhar por este aviso.

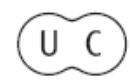




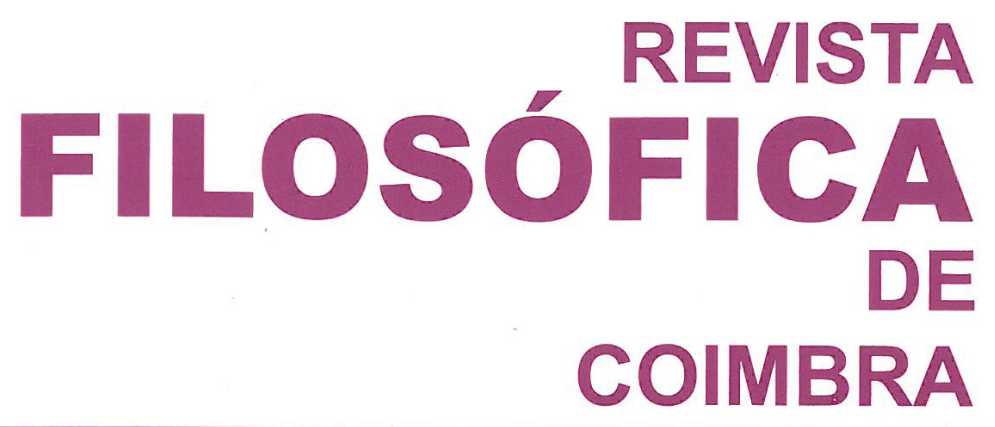

vol. 20 - número 39 - março 2011

vol. 20 - número 39 - março 2011

Fundação Eng. António de Almeida

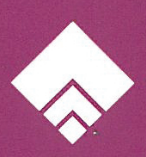




\section{A IDEIA GERAL DO “ACONSELHAMENTO FILOSÓFICO”. UMA INTRODUÇÃO AO TEMA.}

FILIPE M. MENEZES*

Resumo: Este artigo ambiciona introduzir o tema e suscitar o debate sobre o chamado "Aconselhamento Filosófico" na comunidade filosófica nacional. Parte da constatação da sua efectiva presença na "literatura da felicidade" e entre o leque, muito heterogéneo, de "técnicas de ajuda", assinalando, de seguida, a falta de enquadramento académico e sócio-profissional das respectivas actividades de investigação e da sua aplicação como área profissional, para dar conta de alguns problemas básicos da sua fundamentação teórica e subsequentes dificuldades ao nível da sua legitimação social.

Enfatizando a dimensão transdisciplinar requerida para o desenvolvimento da área, coloca o problema da determinação da sua especificidade enquanto actividade filosófica propriamente dita, propondo, para efeitos de sistematização de um estudo sobre essa possibilidade, a constituição de uma plataforma de trabalho que conjugue os esforços da comunidade universitária com os que vêm já sendo postos em marcha por investigadores, fora das universidades, "no terreno".

Procura-se dar conta dos traços característicos da ideia geral de Aconselhamento Filosófico, tal como aparece na literatura e independentemente das variações assumidas pelos diferentes autores, mantendo-se, porém, a devida distância crítica em relação a alguns dos seus pressupostos habituais e sugerindo-se, em contrapartida, algumas linhas orientadoras para uma ulterior investigação: propõe-se uma articulação das noções de "limites de observação", "experiência prática da individuação", "oportunidades selectivas de sentido" e "devolução do desassossego", como uma das possibilidades de iniciar o trabalho de delimitação da prática de "Aconselhamento Filosófico" no sentido de uma aplicação especificamente filosófica à ajuda à orientação do indivíduo na sua relação pessoal consigo mesmo.

\footnotetext{
* Colaborador LIF - Linguagem, Interpretação e Filosofia.
} 
Palavras-chave: "Aconselhamento Filosófico", Filosofia, ajuda, literatura da felicidade, complexidade, limite de observação, individuação, desassossego, orientação.

\begin{abstract}
This article aims at introducing the topic and stimulating the debate about the so-called "Philosophical Counseling" in Portuguese philosophical community. It starts finding the actual presence of the theme in the "literature of happiness" and among a very wide range of " assistance techniques", indicating then the lack of an academic and socio-professional frame of the correspondent research activities and their application as a professional area, to give an account of some basic problems of its theoretical setting and subsequent difficulties regarding its social legitimacy.

Emphasizing the transdisciplinary dimension required to the development of this area, it places the problem of the determination of its specificity while philosophical activity itself, by proposing, for the purposes of systematization of a study about this possibility, the constitution of a working platform that combines the efforts of the University's community with those who have already been put in motion by researchers, outside the universities, "on the ground".

I seek to give an account of the characteristic features of the general idea of "Philosophical Counseling", as it appears in literature and regardless of theoretical differences undertaken by different authors, keeping in mind, however, the critical distance regarding some of its usual assumptions and suggesting, on the other hand, some guidelines for further research: an articulation of the concepts of "limits of observation", "practical experience of individuation", "selective opportunities of meaning" and "devolution of disquiet", is proposed as one of the possibilities of starting the task of delimitation of the practice of "Philosophical Counseling" in the sense of a specifically philosophical aid to orientation of individuals in their personal relationship with themselves.
\end{abstract}

Keywords: "Philosophical Counseling", Philosophy, help, literature of happiness, complexity, observation limits, individuation, disquiet, orientation.

\title{
Introdução
}

A ideia de Aconselhamento Filosófico, surgida em finais do século passado, delimita uma zona de intersecção entre as noções de "Filosofia" e "ajuda". Na sua expressão mais básica, designa um serviço em que um filósofo ajuda alguém a filosofar. Não apenas como um professor que ajuda os seus alunos ao longo do processo de aprendizagem, mas como alguém que orienta o seu esforço no sentido de uma produção de efeitos da actividade filosófica sobre a qualidade da experiência. 
Nela estão pressupostas as ideias de um acréscimo de qualidade ao nível da capacidade de organização das ideias de uma pessoa por meio do trabalho filosófico, e de que uma melhoria a esse nível pode traduzirse em efeitos qualitativos ao nível da capacidade de interpretação de vivências, de tomada de decisões práticas, de resolução de problemas de convivencialidade, etc.

Estes pressupostos formam a base da aposta de uma aplicação da Filosofia e do filosofar a sentimentos de insatisfação, de tristeza, melancolia e frustração e, por conseguinte, ao bem-estar emocional, à saúde do aparelho psíquico e ao equilíbrio de funções vitais.

Isto não significa que o significado do $\mathrm{AF}$ se esgote nesta aplicação à saúde e ao bem-estar, podendo assinalar-se outras possibilidades: a aplicação do AF ao ensino e à aprendizagem é uma das mais importantes, mas também é referida a sua aplicação em empresas, instituições políticas, centros de investigação científica, penitenciárias, etc.

Além disso, nada impede que a ajuda se direccione, simplesmente, para a compreensão ou desenvolvimento de problemas ou de temas abstractos sem qualquer referência à relação entre trabalho filosófico, emoções e sentimentos, ideais políticos, necessidades de outras disciplinas, ou interacção humana nas organizações.

Não obstante esta pluralidade de aplicações possíveis do AF, pode-se resumir a intersecção entre Filosofia e ajuda numa ideia de orientação: o AF ajuda o indivíduo a orientar-se com recurso a instrumentos de trabalho e a conteúdos filosóficos.

É neste cruzamento entre filosofia, ajuda e orientação, que se deve procurar a especificidade do AF: ele não é apenas uma orientação, nem uma ajuda à orientação, mas ajuda a uma orientação especificamente filosófica.

Esta é a base da ideia geral do Aconselhamento Filosófico e a fonte da maioria dos problemas teórico-práticos que se lhe colocam. No entanto, a realidade do Aconselhamento Filosófico não pode ser apenas explicada pelo aparecimento da sua ideia na mente de um pensador criativo, exigindo passar-se ao plano da comunicação em que o tema encontrou as suas possibilidades não apenas como um discurso capaz de envolver um elevado número de intervenientes e interessados, mas também como conjunto de actividades e serviços já efectivamente praticados e que remetem para outras formas de comunicação.

O ponto de vista da comunicação é imprescindível para perceber como se tornou possível o aparecimento da ideia e da realidade do Aconselhamento Filosófico e é necessário para determinar a sua posição, o seu valor e a sua função no conjunto das ideias, dos serviços e dos bens a que podemos chamar "indústria" de ajuda ou de orientação. 
Dele também nos podemos servir para tentar perceber o processo mediante o qual certas funções de identificação e solidariedade moral tradicionalmente associadas à Religião e à Política se estenderam ao âmbito da ciência, em particular da Medicina e da Psicologia, e o movimento ao longo do qual se foi estruturando o cruzamento semântico entre salvação, felicidade e saúde, que deu origem à concepção de sofrimento como uma desordem, uma disfunção, ou mesmo uma enfermidade, e que acabou por conduzir a uma indefinição, por ampliação, da noção de saúde e, por fim, às dificuldades de determinação científica das fronteiras entre saúde e doença ou normalidade e desvio e à reivindicação de um tratamento não clínico do sofrimento individual.

Estamos diante de um fenómeno que só pode ser plenamente compreendido à luz de uma evolução em que a reprodução das estruturas, elementos e operações do sistema da sociedade aprendeu a servir-se de liberdades individuais (e talvez já delas não possa prescindir) geralmente referidas através de noções como auto-determinação, projecto de vida, preferência individual, autonomia de pensamento, etc. Mas podemos duvidar acerca da eficácia semântica destas noções ou questionar até que ponto, do ponto de vista da sociedade, contêm mais do que uma função ideológica. Não é líquida a capacidade significativa destas noções em relação ao processo social de geração de liberdades nem a sua capacidade de aproveitamento das possibilidades de auto-observação que o sistema da sociedade hoje proporciona - e muito menos das vantagens que preconizam em termos de orientação.

No entanto, de algum modo, o aparecimento do Aconselhamento Filosófico é uma manifestação dessas liberdades que a sociedade aprendeu a incluir no seu funcionamento ao serviço da sua coesão e não pode deixar de ser sob a pressão dessas liberdades que uma pessoa procura ajuda filosófica para uma orientação individual no plano da experiência do pensamento e da comunicação.

Ora, em grande parte, a realidade actual do Aconselhamento Filosófico e muito do que compõe a sua literatura raramente evidenciam estes problemas, o que sugere uma certa precipitação ou uma insuficiência de instrumentos de análise que devem ser colmatadas. Não está apenas em causa a possibilidade de construção de uma nova disciplina teórica, mas sim os perigos inerentes às finalidades de uma ajuda que não visa apenas aprofundamentos intelectuais mas que se dirige também à qualidade da vida emocional e, indirectamente, à saúde física, psíquica e social.

O Aconselhamento Filosófico é já uma realidade praticada em consultórios privados um pouco por todo o mundo e também em Portugal. No entanto, no nosso País, esse investimento e os respectivos riscos estão a ser assumidos praticamente apenas fora das universidades, não 
existindo formação idónea na área nem qualquer tipo de regulamentação profissional. Não há notícia de envolvimento directo e sistemático dos filósofos universitários na discussão do tema, com o duplo prejuízo de não se estar a beneficiar do seu contributo para construção de uma área filosófica solidamente sustentada nem das suas capacidades críticas que permitiriam corrigir debilidades e pôr travão em alguns abusos.

Com este texto, ambicionamos despertar o interesse da comunidade filosófica em Portugal em relação ao tema do Aconselhamento Filosófico. Limitamo-nos a propor um ponto de partida para a investigação e para o debate e estaria alcançado o nosso objectivo se pudéssemos contar com a sua crítica - mesmo com a mais severa. De facto, a realidade do Aconselhamento Filosófico só tem a ganhar com essa crítica, quer por meio dela se corrijam e melhorem as bases sobre as quais se poderá levar a cabo a sua construção, quer resulte numa refutação plena da possibilidade de uma área de ajuda filosófica. O que há a ganhar com essa crítica será sempre mais valioso do que tudo o que com ela se venha a perder.

Ao longo deste trabalho, procuraremos descrever os aspectos mais relevantes da realidade do Aconselhamento Filosófico, assinalando a aposta comum que subjaz a todas as suas manifestações, destacando a importância do facto de se tratar de uma área muito recente em que a luta por um reconhecimento académico e social é pelo menos tão viva como a discussão dos fundamentos e das metodologias, e argumentando em favor das vantagens de uma colaboração sistemática entre o trabalho filosófico nas instituições de ensino superior e aquele que tem sido feito fora das universidades.

De seguida, procuraremos clarificar o significado, as potencialidades e os limites do triplo cruzamento entre Filosofia, ajuda e orientação, que define a ideia geral de Aconselhamento Filosófico. Procederemos a algumas aproximações entre Aconselhamento Filosófico e outras actividades, como o ensino da Filosofia e o que designámos "outras actividades de ajuda", a fim de clarificar até onde for possível, nesta fase inicial do trabalho, o que especifica o Aconselhamento Filosófico segundo a ideia geral que dele propomos.

Seguidamente, problematizaremos a noção de "experiência" sobre a qual assenta essa ideia geral de Aconselhamento Filosófico e questionaremos o ponto de vista que vê no "desassossego" provocado por uma carência de sentido a fonte do sofrimento que leva alguém a pedir ajuda filosófica. Estabeleceremos como ponto de partida para a prática do Aconselhamento Filosófico as exigências de um rigor sensivel e proporemos como seu limite uma devolução do desassossego que permita a orientação individual pela abertura de novas possibilidades selectivas de construção de sentido. 


\section{O AF é uma realidade}

O "Aconselhamento Filosófico" (AF) é uma realidade. Não se trata de saber se um dia existirá uma prática com esse nome ou outros congéneres. Podemos perguntar o que é, em que se fundamenta, como trabalha, que resultados visa, se funciona. Mas não podemos ignorar a sua existência.

Em todos os continentes e em muitos países nesses continentes proliferaram, nos últimos trinta anos, gabinetes ou consultórios de AF. Uma pesquisa na web rapidamente o confirma ${ }^{1}$. Encontrar-se-á informação sobre consultórios privados, sobre gabinetes associados a clínicas médicas, a empresas dedicadas ao "bem-estar", a associações culturais, sobre consultórios online e muito mais. É ainda possível colher uma ideia geral dos serviços que se propõem e dos preços praticados.

Da realidade do AF faz ainda parte a oferta de "cursos". Uma parte deles dirige-se à população em geral e funciona como uma espécie de aulas práticas de auto-ajuda ${ }^{2}$, em que se oferece um treino inicial para lidar com questões "existenciais" ou dilemas éticos. A outra parte destina-se aos interessados em tornarem-se "conselheiros filosóficos"3. Estes são, regra geral, licenciados em Filosofia ou detentores de outros títulos académicos mais avançados na área, mas também são frequentados por pessoas com outras formações, habilitações e aspirações. Em vários sites, encontramse também anúncios a estudos pós-graduados em algumas instituições de ensino universitário ${ }^{4}$.

É também uma realidade no sentido de produção e publicitação literárias. A bibliografia disponível sobre o assunto é heterogénea e

${ }^{1}$ Cf., por exemplo, a lista de praticantes registados nas listas da American Philosophical Practioners Association: http://www.appa.edu/counselors.htm (15 de Julho de 10).

2 Cf., por exemplo, na School of Economic Science, Londres: http://www.philosophycourse.com/ (2 de Julho de 2010).

3 Exemplo de um caso da oferta brasileira no âmbito da "filosofia clínica" é o do Instituto Lúcio Pakter: http://www.filosofiaclinicaonline.com.br/ (16 de Julho de 10).

${ }^{4}$ Cf., por exemplo: Scuola Superiore di Counseling Filosofico, Roma: http://www.sscf. it/; Istituto di Filosofia e di Antropologia Clínica e Esistenziale, Roma: http://www.ifacecrf. it/; Università ca' Foscari Venezia - Dipartimento di Filosofia e Teoria delle Scienze: http:// venus.unive.it/master-cofil/; Universidad de Barcelona (Departamento de História da Filosofia, Estética e Filosofia da Cultura): http://www.ub.edu/practicafilosofica/;Universidad; Universidade de Sevilla: http://www.cfp.us.es/web/ficha_avanzada.asp?id titulo=10\&tip $\underline{\mathrm{o}=\mathrm{MU} \& \text { basica=1\&ci=1; Waikato Faculty of Education, New Zeland: http://edlinked.soe. }}$ waikato.ac.nz/programmes/index.php?prog_id=34; Centro de Filosofia Clínica de Poços de Caldas, Brasil: http://www.centrofic.com.br/index.php?secao $=\mathrm{c} 001$. Também a Universidade do Porto oferece já uma oficina de trabalho em "Filosofia Prática e Pensamento Crítico": http://sigarra.up.pt/reitoria/noticias geral.ver noticia?p nr=772. (16 de Julho de 10). 
nela se misturam com grande arbitrariedade esquematizações dirigidas a leigos, publicidade a cursos de auto-ajuda, anúncios de serviços, actas de conferências, pequenos ensaios, compilações de "métodos", resumos do "nascimento e história" do AF, etc.

Dada a amplidão de fenómenos a que hoje podemos chamar literatura sobre um determinado tema, podemos ainda incluir reportagens, entrevistas (mesmo as entrevistas radiofónicas se incluem, de certo modo, no que chamamos "literatura de AF"), pequenas notícias em jornais nacionais e muito do que se faz na Internet, nomeadamente os blogs pessoais, os comentários que aí se podem registar, os fóruns de discussão, as "redes sociais", ...5

Este é um dos aspectos da realidade do AF que marca a sua proximidade com outros fenómenos cuja compreensão será necessário ter em conta na discussão acerca das suas possibilidades, limites e valor e em qualquer apreciação que sobre ele se pretenda relevante. Não pode deixar de se considerar a efectiva intersecção entre regiões da "literatura de AF", da "literatura de ajuda" e da "literatura de felicidade" no processo de construção teórica do AF, na sua definição metodológica e na sua avaliação.

Para além do aparecimento de consultórios e da proliferação literária de livros, artigos, revistas da "especialidade", páginas web, blogs, e outras publicações, a realidade do AF inclui ainda a actividade de organizações socioprofissionais que reúnem praticantes de $\mathrm{AF}$ e que procuram atrair novos associados, divulgar consultas e conquistar alguma visibilidade nos media, promovendo actividades como workshops, cursos, cafés filosóficos, palestras, conferências, etc. ${ }^{6}$

${ }^{5}$ Adaptamos ao nosso tema a expressão "literatura da felicidade", de que G. Bueno parte para as suas análises das bases metafísicas da semântica da felicidade. Gustavo Bueno, El mito de la felicidad - Autoayuda para desengaño de quienes buscan ser felices (Barcelona: Ediciones B, 2005).

${ }^{6}$ Alguns exemplos deste tipo de organizações: http://www.appa.edu/ (American Philosophical Practioners Association); http://www.society-for-philosophy-in-practice.org/ (The Society for Philosophy in Practice); http://www.aspcp.org/ (American Society for Philosophy Counselling \& Psychoterapy); http://www.asepraf.org/ (Asociación Española para la Práctica y el Asesoriamiento Filosóficos); http://www.fabbricafilosofica.it/ (Associazione di filosofia applicata "Fabrica Filosofica"); http://www.sicof.it/ (Società Italiana di Counseling Filosofico) http://fundacionfilosofarte.com/filosofarte.htm (Fundación Colombiana para la práctica y asessoriamento filosóficos "Fundación Filosofarte"); http:// www.igpp.org/eng/igpp_start.asp (Internationale Gesellschaft für Philosophische Praxis); http://www.redfilosofica.de/sopecprafil.html (Sociedad Peruana de Consejería Filosófica y Prática Filosófica); http://www.verenigingfilosofischepraktijk.nl/index.php (Vereniging voor Filosofische Prakttijk); http://apefp.blogspot.com// (Associação Portuguesa de Ética e Filosofia Prática). (15 de Julho de 10). 
A cada um destes aspectos que constituem a realidade do AF diz ainda respeito a questão da divulgação. Consultas, literatura, organizações, cursos - em todos estes aspectos, a realidade do AF tanto é marcada pelo entusiasmo de "pioneiros" honestamente convictos de que laboram sobre uma possibilidade de aplicação válida e interessante de competências e conhecimentos filosóficos a situações concretas, como pela tentativa de construir, divulgar e implementar no mercado uma nova profissão. É difícil ver como podem estes dois lados de uma mesma moeda dissociar-se um do outro, ou melhor, como poderia divulgar-se e tornar-se apelativa esta prática se apenas houvesse preocupação com questões de imagem de marca e se descurasse o trabalho de construção da ideia e da prática propriamente ditas. No entanto, o ímpeto sedutor acaba, por vezes, por se sobrepor ao trabalho de construção e divulgação consistente, arriscando-se talvez em demasia as possibilidades de desenvolvimento do serviço de AF como actividade profissional bem sucedida.

A realidade do AF caracteriza-se, para já, em Portugal, pela sua inexistência formal como profissão ou actividade económica ${ }^{7}$. Não é reconhecida por nenhuma lista de ocupações profissionais do País, nem lhe é conferida uma correspondência fiscal exactamente definida. Nenhum documento oficial determina a formação mínima necessária para se exercer a profissão. Não existe nenhuma ordem nem sindicato para o sector. Neste momento, em princípio, qualquer pessoa pode iniciar e publicitar a sua actividade como "conselheiro filosófico". Isto significa que pessoas sem qualquer preparação podem estar agora mesmo a lidar com situações que exigem a maior competência e responsabilidade. Significa também que se torna possível propagar a ideia de que algumas associações existentes detêm o monopólio na formação e na regulação dos profissionais e, assim, sugestionar as expectativas daqueles que avistam na área a oportunidade de uma profissão.

Importa realçar que a realidade do AF tem, sobretudo, o carácter de uma aposta. O que motiva os que nele apostam, o que apostam, como apostam ou que tipo de retorno esperam, não é possível adivinhar. Podemos apenas imaginar que poderá tratar-se de filósofos que acreditam ter tido uma boa ideia e que procuram pô-la à discussão, ou de investigadores que procuram testar o interesse dessa ideia; poderá tratar-se da aposta de introduzir um ramo de especialização opcional na oferta curricular de um departamento, ou da aposta de abrir um consultório ou escrever um livro

7 Cf.http://portal.iefp.pt/portal/page?_pageid $=177,182931 \&$ dad=gov_portal_iefp\&

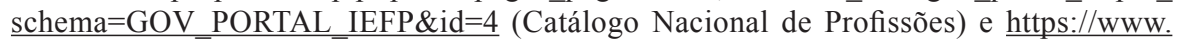
ccdrc.pt/index.php?option $=$ com content $\&$ view $=$ article $\&$ id $=148 \&$ Itemid $=122 \&$ lang $=p t$ (Classificação Portuguesa de Actividade Empresarial) (15 de Julho de 10). 
sobre o assunto. Nesta fase muito embrionária do seu desenvolvimento, é quase tão impossível evitar o confronto com a questão dos riscos numa aposta no AF como com o entusiasmo que a ideia de uma ajuda filosófica pode gerar.

Devemos recordar-nos com frequência, porém, que quem faz a maior aposta é a pessoa que procura ajuda junto de um "conselheiro filosófico". E, sendo assim, é ela quem verdadeiramente corre os riscos mais importantes - porque, dado o espectro de expectativas que em relação ao AF se podem constituir em virtude da sua proximidade com a "literatura de felicidade", e dada a falta de regulação da profissão e, sobretudo, da garantia de boas oportunidades de formação, estará de certa forma a arriscar colocar-se à mercê da incompetência, da falta de bom senso e de responsabilidade e, sem que nada verdadeiramente o possa contrariar, até mesmo da mais completa ausência de escrúpulos.

Visto não existirem estudos conhecidos sobre os efeitos terapêuticos do AF nem acerca dos seus resultados sobre a vida emocional das pessoas que o procuram, a formulação de uma ideia geral de AF deverá ter em conta o seu carácter de aposta também no sentido em que não é cientificamente evidente a contribuição do trabalho realizado no plano das ideias para o "bem-estar" dessas pessoas. Existe a este respeito, nos meios de investigação e debate sobre AF, uma elevada expectativa, mas esta funda-se apenas no feedback que os praticantes afirmam ter recebido de consultantes e/ou em derivações teórico-argumentativas que podem ser mais ou menos verosímeis, mas estão longe de um tratamento científico. Neste momento da sua construção, não pode perder-se de vista esta perspectiva do AF como aposta.

O AF reúne um conjunto muito heterogéneo de ideias, de comunicações e de actividades agrupadas sob um ou vários nomes congéneres, como Filosofia Aplicada à Pessoa, Acompanhamento Filosófico, Consultoria Filosófica, Prática Filosófica, Orientação Racional, Filosofia Clínica, Assessoria Filosófica, Orientação Filosófica, etc. Esta pluralidade difusa constitui uma janela de desafios e oportunidades baseada na ideia de que filosofar pode ajudar. O facto de nesta base se mesclarem as ideias de "Filosofia" e de "ajuda", levanta uma série de problemas e impõe certas condições, sem cuja resolução ou satisfação dificilmente se alcançará sucesso na construção do AF.

Para que esta construção se torne possível, é necessário determinar que área em comum podem cobrir a actividade filosófica e a ajuda, o que envolve a mobilização de recursos e uma organização do trabalho que excedem o âmbito, ainda muito frequente no nosso País, de investigadores ou praticantes "auto-didactas" operando de forma relativamente isolada. 
Dada a falta de enquadramento institucional, muito do trabalho sério que possa estar a ser realizado, independentemente da competência de quem o realiza e da qualidade obtida, corre o risco de passar despercebido ou de passar a ser irremediavelmente associado a práticas menos fundamentadas, votando-se assim ao descrédito.

\section{Aspectos básicos da construção e legitimação do AF como práti- ca de ajuda especificamente filosófica}

O AF é uma realidade cuja construção está longe de se poder tomar como avançada, tal como a ideia de que filosofar pode ajudar está a léguas de uma explicitação e justificação suficientemente claras. O seu reconhecimento como disciplina filosófica é ainda muito diminuto e, apesar de muitos esforços em sentido contrário, não é um serviço de que a generalidade da população tenha sequer a menor noção.

De seguida, procuraremos esquematizar alguns aspectos que nos parecem formar requisitos básicos para o prosseguimento da construção do AF e para a sua capacidade de se legitimar como prática de ajuda específica. Veremos que estes aspectos permitem pensar numa série de conexões entre o AF, outras áreas disciplinares e a própria Filosofia. Argumentaremos, então, a favor das vantagens de estabelecer plataformas de colaboração entre os investigadores e praticantes auto-didactas já no terreno e investigadores e docentes do ensino superior.

\subsection{Requisitos mínimos}

A validação do AF supõe um exercício de fundamentação e confrontação com a experiência, um programa de investigação, condições para o pôr em prática, situações "laboratoriais" para testagem, definição de esquemas de observação e avaliação, confronto de pontos de vista e partilha sistemática de resultados. É preciso tempo. É precisa a disponibilidade, a motivação e a competência de investigadores. São necessários os meios materiais para que todas as condições anteriores possam operar. E é necessária a presença do "objecto" de trabalho.

Como se vê, impõe-se, em vários níveis, investimento, o que se relaciona obviamente com o carácter de uma aposta numa área que apenas se encontra na fase inicial do seu desenvolvimento. Nota-se, por um lado, um certo entusiasmo por parte de alguns investigadores e praticantes. Alguns deles abriram consultórios e afirmam ter recebido retorno positivo do seu trabalho, talvez mais a nível da satisfação do "consultante" do 
que em termos económicos. Chega-se mesmo a referir uma certa moda da filosofia, ilustrando-se o mesmo com a curiosidade que alguns temas filosóficos têm suscitado nos media e junto dos editores. Mas esta onda de optimismo não encontra ainda correspondência num interesse alargado da comunidade científica ou da população em geral pelo AF, pelo menos em Portugal. É esta confiança que, para além da banalidade e dos episódios de menor credibilidade que a "literatura" permite sobre o tema, o discurso sobre AF tem que saber capitalizar, para que se possam vir a interessar pelo tema os próprios filósofos, as instituições vocacionadas para o acolhimento de formações e, finalmente, a população que, neste momento, provavelmente nunca ouviu falar de AF.

A questão da confiança é, com efeito, primordial, o que se vê com toda a clareza pelo facto de que, para a sua construção disciplinar, o AF requer momentos de "experimentação", logo, "visitantes"8 motivados e dispostos a efectuarem uma experiência de consulta de AF, e, portanto, confiantes na ideia de AF e no profissional que se lhe dedica. Esta questão da confiança é tão importante que não nos podemos permitir iludi-la, e pouco se adiantará se se pretender fabricá-la com leveza retórica, como por vezes acontece na "literatura de AF".

Em boa parte, essa confiança depende da existência de condições de habilitação e certificação profissional. As duas condições são simultaneamente necessárias: sem a habilitação suficiente, a certificação rapidamente é desacreditada; com a habilitação mas sem a certificação, torna-se difícil obter a confiança. Estes aspectos devem ser considerados forçosamente antes de se poder passar à preocupação com outras questões, também importantes mas secundárias em relação a estas, como por exemplo as que dizem respeito ao reconhecimento oficial do AF como profissão ou as que se referem ao associativismo dos profissionais. Sem investigação, sem formação e sem a confiança nelas fundada, o AF não terá sucesso como profissão.

Perguntar se o AF é possível é também perguntar se ele funciona, se introduz uma diferença na vida de alguém que avalia essa diferença como satisfatória. Essa é uma pergunta, que certamente, farão, ainda que seguramente segundo critérios diferentes, aqueles que se confrontam com a hipótese do AF: investigadores, formadores, formandos, organizações, estabelecimentos de ensino e consultantes. Independentemente das motivações de cada um destes possíveis intervenientes, a todos eles convirá que o AF em que ponderam de algum modo investir seja capaz de produzir resultados, no sentido de uma contribuição para operar uma certa mudança favorável para aquele que desejou essa mudança. A necessidade

\footnotetext{
${ }^{8}$ A expressão é de Gerd Achenbach, frequentemente indicado como fundador do AF contemporâneo.
} 
de apresentar resultados é, até certo ponto, nesta fase, uma das condições para produzir resultados. Para isso, é necessário sistematizar formas de avaliação e de comunicação sobre a mesma.

O ponto de vista da apreciação do AF pela diferença que ele introduz na vida de alguém tem a vantagem de introduzir directamente uma referência ao problema do cruzamento entre o que motiva uma pessoa a procurar ajuda de AF e o serviço que este se propõe prestar-lhe. A validade dos resultados da consulta de AF depende da validade deste cruzamento. E esta última requer o cumprimento de prerrogativas a que o AF não pode renunciar, nomeadamente, a de que ele é, como qualquer outra actividade filosófica, definido pelo acto de filosofar. Mas, a primeira grande especificidade do AF é a de que é uma actividade filosófica que pretende ajudar, razão pela qual o AF não se pode livrar dessa outra prerrogativa que é a de que aquele filosofar termina no momento em que deixa de ser considerado favorável. Qualquer intenção de avaliar o funcionamento de uma consulta deve ter em conta esta exigência de rigor sensivel - uma avaliação que se baseie apenas ou no acto de filosofar ou no alívio da perturbação é avaliação equívoca e não permite uma apreciação do AF.

Isto significa que para validar o AF é necessário determinar tanto quanto seja possível o âmbito da sua aplicação, reconhecer o melhor possível quando se está prestes a entrar noutro domínio, por exemplo, na Psicologia ou na Religião, mantendo-se ainda assim sensível à fragilidade, sofrimento ou perturbação em que provavelmente se encontra quem pediu ajuda.

Este cruzamento entre rigor e sensibilidade tem sido em grande parte responsável pela necessidade, tão frequentemente enfatizada na "literatura", de uma afirmação do AF pela demarcação do seu espaço próprio em relação a outras áreas de "ajuda", em especial a Psicologia, a Psiquiatria e a consolação espiritual proporcionada pela Religião. O reconhecimento do AF só estará completo quando for possível indicar o que é que ele acrescenta ao que as outras áreas já oferecem e que tipos de conexões se devem proporcionar ou evitar entre essas áreas.

O esforço a que tudo isto obriga implica uma organização mais formal, sistemática e comunicativa do trabalho de investigação em AF, do que aquele que até agora tem sido possível.

A construção do AF não pode, além de tudo o que já foi assinalado, deixar de ser um dos aspectos principais da sua dimensão filosófica, o que lhe impõe a capacidade de se justificar a si mesmo, não só face às outras áreas de ajuda como diante de si mesmo. Não lhe basta indicar o que se propõe fazer e em que termos, nem o satisfaz definir os limites da sua aplicação e os critérios da sua avaliação, devendo acrescentar a 
tudo isso uma explicação da sua possibilidade, da sua razão de ser e da razão de hoje se pensar que pode haver pessoas a cujos pedidos de ajuda é possível responder com uma actividade filosófica.

Está implícito, portanto, um meta-programa de auto-reflexão dedicado a estudar o significado da sua concretização histórica num determinado momento da evolução da sociedade, à luz das possibilidades e das condições de observação que, nesse momento, a sociedade a si mesma propõe.

Mas, mesmo admitindo a possibilidade de que a satisfação de todas estas condições esteja assegurada, a validação do AF enfrentará ainda outras dificuldades. Nomeadamente, a da sua divulgação, sem a qual dificilmente conquistará um lugar entre os serviços das áreas da cultura e do "bem-estar". Estas são áreas com grande potencial de desenvolvimento económico, o que as torna aliciantes, mas também altamente competitivas. Deste ponto de vista, o reconhecimento e a implementação do AF dependerão também, a jusante, da capacidade de o AF se fazer notar e credibilizar.

\subsection{Aconselhamento Filosófico, Filosofia e outras áreas disciplinares/ serviços}

Como o sugere a designação, o AF aspira ao estatuto de uma disciplina, ramo ou aplicação da própria Filosofia. No entanto, a sua realidade e alguns dos fenómenos a que está ligada, poderão suscitar o interesse de diferentes actividades e áreas do conhecimento. Destas, por outro lado, terão certamente a colher-se importantes contributos para a construção do AF. Assim, a qualidade de uma actividade especificamente filosófica não impede, pelo contrário suscita, o envolvimento de outras disciplinas, com previsíveis vantagens para todas.

A multidisciplinaridade é uma condição necessária do desenvolvimento do AF e deve ser tida em conta na sua construção teórica como nas suas aplicações. Tal como acontece com a Filosofia em geral, o AF não pode ignorar as aquisições científicas das outras áreas disciplinares nem as potencialidades e problemas teórico-práticos que delas advêm. Por outro lado, é possível que, tal como tem acontecido os filósofos serem chamados a debates sobre temas e problemas específicos de outras áreas ${ }^{9}$,

${ }^{9}$ Cf. A título de exemplo, KWB Fulford e Giovanni Stanghellini, 'Dialogues in Philosophy, Mental and Neuro Sciences', $2009<\mathrm{http}$ ://www.crossingdialogues.com/fulford. htm>. Maria José Cantista (Coord.), A Dor e o Sofrimento - Abordagens (Porto: Campo das Letras, 2001). Maria Luísa Portocarrero, Daniel Serrão e Luís António Umbelino, Corpo Saúde e Espaço Público, Cadernos do LIF, n. 22 (Coimbra: Ariadne Editora).Philosophy, Psychology and Psychiatry, ed A. Phillips Griffiths (Cambridge: Press Syndicate of the University of Cambridge, 1994). 
nomeadamente no campo das Ciências Médicas e da psicoterapia, algo semelhante venha a ocorrer com o AF.

Privilegiamos, de seguida, sem qualquer pretensão de esgotar o tema, sumariar alguns aspectos que poderão suscitar o interesse de outras áreas pelo $\mathrm{AF}$, dado que ao interesse do $\mathrm{AF}$ pelas mesmas se chega, provavelmente, de forma muito mais intuitiva.

1. Psicologia, Psiquiatria, Neurologia, Medicina Geral, etc., poderão interessar-se pela sugestão típica do AF de que o cuidado com o arranjo das ideias ligadas ao nosso sentido mais ou menos silencioso do que a vida significa honesta e profundamente, e relativas à nossa forma individual de ver e sentir a força e a pressão total do $\operatorname{cosmos}^{10}$, poderá traduzir-se em resultados benéficos ao nível da saúde, em acréscimos de auto-estima, em benefícios motivacionais, em enriquecimento das potencialidades criativas, em capacidades de concentração, em diminuição da ansiedade e do stress, etc. A natureza das acções recíprocas entre o plano da organização de ideias, o funcionamento do aparelho psíquico e estruturas e funções biofisiológicas promete uma interessante linha de estudo.

2. As Ciências da Educação reconhecem a importância e a abrangência do papel da exercitação de competências desenvolvidas pela actividade filosófica no progresso das aprendizagens em outras áreas do saber, nos processos necessários à sua síntese para a compreensão do mundo em que vivemos e para o aprofundamento da cidadania e, em geral, para o que se tem designado de "formação integral" 11 .

Apesar de um certo sentimento, amplamente partilhado na comunidade de docentes do Secundário, de uma certa desvalorização da disciplina de Filosofia nos currículos nacionais, aquele reconhecimento básico tem proporcionado a discussão em torno da chamada filosofia para crianças. Além disso, a importância da actividade filosófica tem sido reconhecida em várias actividades extra-curriculares, como

10 Esta formulação do que é a Filosofia é de grande interesse para o AF, uma vez que estabelece claramente a conexão entre a reflexão filosófica e a experiência, na qual se baseia toda a sugestão de um ramo da Filosofia com aplicação ao nível da ajuda. Encontramo-la em William James, O Pragmatismo - um nome novo para algumas formas antigas de pensar (Lisboa: Imprensa Nacional Casa da Moeda, 1997), p. 27.

${ }^{11}$ Esta é, aliás, a grande linha argumentativa de que se serve o texto do Programa de Filosofia dos $10^{\circ}$ e $11^{\circ}$ anos para se justificar como componente de formação geral do Secundário. Poderá consultar-se o referido texto em:

http://www.dgidc.min-edu.pt/recursos/Lists/Repositrio\%20Recursos2/Attachments/221/ filosofia_10_11.pdf (16 de Julho de 10). 
por exemplo os "clubes" oferecidos pelas escolas, ou os workshops extra-curriculares abertos a toda a comunidade educativa, e chega-se mesmo a discutir informalmente a possibilidade de criação de gabinetes de AF ou da sua cooperação com os Serviços de Psicologia e Orientação das escolas. Desconhecemos, todavia, planos de estudo na área educativa acerca da possibilidade de introdução do AF em equipas multidisciplinares escolares dessa natureza. Seja como for, seria útil tratar de forma mais sistemática a questão dos benefícios da actividade filosófica extra-curricular para o sucesso das aprendizagens escolares e do desenvolvimento pessoal do jovem.

3. Há também aspectos sociológicos que merecem ser estudados, nomeadamente no que diz respeito às possibilidades e ao significado social do aparecimento de novas actividades dedicadas à organização simbólica de processos de construção de identidade, de definição individual de metas e fins da vida tomada como projecto pessoal, de edificação moral da personalidade, etc., actividades essas que não podem ser enquadradas nos sistemas religioso, político, artístico, familiar, educativo, de saúde ou científico, e em relação às quais será necessário determinar a posição do AF.

4. Pode-se estudar o interesse do AF do ponto de vista económico. Por exemplo, pode perguntar-se acerca da sua capacidade para gerar empregos. Podem averiguar-se também os resultados nas capacidades produtivas das pessoas que pedem ajuda ou quanto às suas aptidões para gerirem produtivamente as suas relações interpessoais em contexto laboral. O caso extremo do "suicídio no local de trabalho" levanta, obviamente, questões que interessam aos filósofos (e aos empresários e entidades políticas) e é hoje impossível não indagar que interpretações se podem esperar para o problema e que contributos apresentarão.

Num outro contexto, vale a pena mencionar o trabalho de Lara Sayão Ferraz, com reclusos numa penitenciária brasileira ${ }^{12}$. A possibilidade de uma ligação profícua entre o $\mathrm{AF}$, as disciplinas ligadas à saúde mental e as "práticas assistenciais" são aqui bastante evidentes.

$12 \mathrm{O}$ texto que serviu de apoio à comunicação pode consultar-se em Lara Sayão Ferraz, 'A necessidade de Exercer o que é Próprio do Homem', em Encontros Portugueses de Filosofia Aplicada, ed Jorge H. Dias (Albufeira: APAEF, 2008), pp. 17-27. A apresentação da sua experiência numa penitenciária brasileira contemplou a projecção de um pequeno filme realizado neste contexto, mas a sua explicitação e comentário foram orais. 
A realidade do AF poderá, como se vê, tornar-se interessante para outras áreas e por outras razões para além das referidas. Mas é, sobretudo, para a própria Filosofia que ela se coloca em primeiro lugar como questão. Pelo menos por duas razões: 1. dada a proximidade entre a realidade do $\mathrm{AF}$ e fenómenos sociais e humanos de grande relevância para várias áreas temáticas da Filosofia, tais como aqueles que vulgarmente se designam através de expressões como "sociedade de consumo", "culto do eu" ou "Estado de Bem-Estar"; 2. porque consiste num projecto que aspira a uma dimensão filosófica tanto ao nível dos seus fundamentos como da sua aplicação, o que, obviamente, implica um tratamento filosófico do tema.

\subsection{A vantagem de uma plataforma de trabalho reunindo universitários e praticantes já no terreno}

A maior parte dos centros de investigação e ensino superior da Filosofia em Portugal têm mantido um certo distanciamento em relação ao fenómeno do AF. Mesmo em outros países onde a actividade está um pouco mais desenvolvida, ainda são poucas, como vimos, as universidades que integram planos de estudo na área. Em Portugal, a sua aceitação nos meios académicos tem sido ainda mais vagarosa.

No entanto, o esforço e os meios investidos na construção e na divulgação do AF não têm sido pequenos, podendo mesmo assinalar-se alguns momentos em que um público alargado dele pôde ter notícia. É o caso do best-seller, traduzido em várias línguas e já com sete edições desde 1999, Plato not Prozac, de L. Marinoff. A própria imprensa portuguesa, a rádio e a televisão, têm revelado alguma curiosidade pelo tema e têm-lhe dado, em várias ocasiões, viva voz. ${ }^{13}$ Não têm faltado, como se referiu anteriormente, iniciativas de organização de conferências ou colóquios ${ }^{14}$ que suscitaram notícias. Por outro lado, até mesmo em Portugal tem já havido ocasião de comunicar sobre AF em encontros científicos pluridisciplinares ${ }^{15}$.

${ }^{13} \mathrm{Cf}$., a título ilustrativo: http://jornal.publico.pt/noticia/11-10-2009/daose-consultas-de-filosofiadaose-consultas-de-filosofia-17962720.htm (12 de Julho de 10).

${ }^{14} \mathrm{Cf}$., para o caso português: VVAA, Actas do I Encontro Português de Filosofia Prática - 2005, ed J. Humberto Dias (Lisboa: APAEF, 2006). Vj. também: VVAA, Encontros Portugueses de Filosofia Aplicada, ed J. Humberto Dias (Albufeira: APAEF, 2008).

${ }^{15}$ Em dois mil e nove, aproveitámos a oportunidade de apresentar uma comunicação sobre o tema na 12th International Conference of Philosophy and Psychiatry. O texto que serviu de suporte à comunicação, inédito à data da redacção deste artigo, é: Filipe M. Menezes, From Philosophy of Psychotherapy to Philosophical therapy - a contribution to a preliminary debate. Suffering and Communication - a peculiar point of view; 24 de Outubro de 2009, Aula Magna, Lisboa. 
Apesar de tudo isto, porém, o AF permanece na penumbra, mal tendo conquistado lugar entre as opções curriculares dos cursos superiores ou pós-graduados de Filosofia, e menos ainda no que diz respeito à capacidade de se dar a conhecer e a confiar ao público em geral.

A verdade é que, em Portugal, a sua construção teórico-prática e a sua imagem pública têm permanecido dependentes da disponibilidade e da habilidade de uns quantos auto-didactas, trabalhando de forma mais ou menos isolada, cujo esforço de investigação, comunicação e divulgação não tem sido, como se vê, suficiente para dar maiores resultados. Entretanto, a par de iniciativas muito sérias e de mérito assinalável, abrem-se também as portas a práticas menos fundamentadas, assentes em perspectivas demasiado redutoras e em conceitos insuficientemente esclarecidos, com todos os perigos que isso acarreta.

Com efeito, sente-se a falta de uma reflexão sistemática acerca das condições de possibilidade do AF e carece-se ainda de uma investigação dos processos mediante os quais foi possível o aparecimento da ideia geral de AF no nosso tempo e na nossa sociedade, e do seu significado. Precisamos de reflectir sobre a coincidência temporal entre este aparecimento e o de uma tendência para o esvaziamento de significado e para a apropriação da terminologia filosófica pela linguagem coloquial. Precisamos de perceber o que significa o aparecimento de uma filosofia super-pop em que se publica literatura na qual Nietzsche chorou, Sócrates usa jeans, ou Platão entra num bar em que se contam anedotas; em que se anuncia quase solenemente, como acontece em certos sites portugueses dedicados à "prática filosófica", que um certo treinador desportivo usou numa entrevista a palavra "filosofia"; precisamos de averiguar o que se passa com a Filosofia quando se torna possível a propagação de literatura em que ela se conjuga, das formas mais improváveis, com todo o tipo de misticismos dogmáticos, esoterismos e "holismos" que hoje se oferecem ao consumo de massas. Seria certamente interessante observar a reacção dos nossos filósofos em relação àquele tipo de palestras (cada vez mais usuais nos centros urbanos) em que tresleituras de Séneca ou de A. Camus se tornam perfeitamente compatíveis com os mistérios incas, a divinação de inspiração cabalística ou a regressão a vidas passadas.

A Filosofia terá forçosamente que reflectir sobre este processo da sua parcial desfiguração social, no qual se integra e para o qual têm contribuído uma boa parte do movimento ligado à "prática filosófica" e da "literatura de AF" a que tem dado origem. Deverá preocupar-se com as relações entre a organização da comunicação na sociedade e o aparecimento de estruturas simbólicas que nela permitem a crença na possibilidade de uma procura de identidade e de consolação moral por meio de uma reflexão racional privada acessível a qualquer um. Deverá perguntar-se pelas ressonâncias 
religiosas, políticas, económicas, científicas e culturais que vibram no fenómeno do AF e, a partir daí, averiguar: 1. Que há de filosófico no AF; 2. O que distingue o AF da vasta corrente do que chamámos filosofia super-pop; 3. A que casos, como, com que objectivos se pode aplicar essa vertente filosófica; 4. Que resultados se podem observar.

Portanto, deverá elucidar se a realidade do AF se reduz inteiramente e em todas as suas expressões e possibilidades à contemporânea indústria de ajuda e à filosofia super-pop, ou se pode dar origem a algo mais sustentado e consistente; se a ideia de AF pode ser sustentada filosoficamente e apoiada em aquisições científicas e, nesse caso, que metodologias se podem propor, que resultados se podem esperar, que questões de ordem ético-deontológica se impõem, que conexões disciplinares são previsíveis, etc.

Podemos agora sintetizar o que há de vantajoso na constituição, em Portugal, de plataformas de trabalho em que possam colaborar formalmente docentes e investigadores universitários de várias áreas disciplinares e investigadores e praticantes já no terreno.

A construção e a legitimação do AF colocam-nos diante de uma exigência de criação de condições trabalho que permitam a definição, implementação e avaliação de um programa de trabalho muito amplo, multidimensional, multidisciplinar também e, sobretudo, filosoficamente articulado. Precisamos da coordenação das "melhores cabeças", de meios de pesquisa, de organização e comunicação, de formação, de credibilidade, de investimento. Beneficiaríamos das sinergias que se poderiam criar a partir do enquadramento deste programa em centros de investigação e de ensino pautados pela exigência, pelo rigor e pela idoneidade.

\section{A ideia geral do AF}

Tentaremos, entretanto, apontar alguns dos traços mais importantes da ideia geral de AF e, de passagem, indicar alguns dos problemas que se lhe colocam.

Numa primeira aproximação, o Aconselhamento Filosófico refere-se à noção de que existem problemas de dimensão filosófica que podem condicionar a qualidade da experiência de pessoas que não disponham, num dado momento, de recursos suficientes para lidar com esses mesmos problemas, o que pode então justificar a prestação de um filósofo profissional aplicando conhecimentos e exercendo competências filosóficas e comunicativas num consultório ou gabinete.

A prática do AF constrói-se, portanto, sobre uma actualização do antigo pressuposto de que há uma ligação de duplo sentido entre a abstracção filosófica e o plano da experiência concreta, que as enriquece 
a ambas: a experiência como ponto de partida para o filosofar; o filosofar como ponto de retorno que, sem sair da experiência, nela introduz novas possibilidades.

Considera-se que na experiência pode haver lugar a dúvidas, perplexidades, inquietações e sofrimentos que concorrem para a formulação pessoal de problemas sobre temas que é possível relacionar com assuntos que têm sido tratados ao longo da História da Filosofia. Na maior parte dos casos em que isso acontece, é provável que o senso mais básico e espontâneo de cada um proporcione formulações e soluções satisfatórias para esses problemas. Mas é possível que não seja esse o caso, e que uma pessoa sinta necessidade de iniciar um processo reflexivo mais sistemático que exige o cumprimento de outros requisitos, como condições especiais de observação e de comunicação, ou recurso a competências que podem não estar suficientemente desenvolvidas ou estão indisponíveis de momento.

Deste ponto de vista, o AF pode ser visto como uma intervenção ao nível da "filosofia pessoal de vida" (considerada esta do ponto de vista das conexões de sentido ao longo do fluxo de experiências), com vista a um aprofundamento e enriquecimento teórico e funcional da mesma ${ }^{16}$.

Sobre esta hipótese, o AF surge como um acompanhamento, um apoio à (re)formulação desses problemas, à (re)colocação de questões, à organização crítica de crenças, ao questionamento axiológico, à ampliação do património conceptual, ao desenvolvimento das capacidades lógicoargumentativas, ao exercício de competências interpretativas e de contextualização, etc.

Mas não se reduz a uma extensão da "filosofia contemplativa", embora se possam admitir casos de consulta cuja motivação se cinge a um impulso de compreensão teórica de certos problemas mais ou menos abstractos. O AF sugere uma aplicação da reflexão de tipo filosófica a situações concretas da experiência individual, capaz de acrescentar algo à compreensão espontânea das mesmas, mas também capaz de repercutir sobre a organização do sentido de ulteriores vivências e acções.

Salvo as situações em que a consulta se dedica exclusivamente ao tratamento abstracto de temas e problemas da tradição filosófica, o AF

16 Torna a ser interessante regressar a W. James: Poucas pessoas têm filosofias próprias articuladas e definidas. Mas quase toda a gente tem o seu próprio sentido peculiar de um certo carácter total do universo (...). William James, p. 39. Na sétima conferência, foi o autor um pouco mais longe: É todavia impossivel dizer que qualquer dos estádios conhecidos [senso comum, ciência e filosofia] é absolutamente mais verdadeiro que qualquer outro. (...) O senso comum é melhor para uma esfera da vida, a ciência para outra, a crítica filosófica para uma terceira. Idem ib., pp. 97 e 98. 
consiste numa permanente tematização da conexão entre a abstracção e a experiência concreta, tratando filosoficamente situações vividas, então veiculadas discursivamente, e procurando servir-se dos avanços ao nível dessa reflexão para construir novas possibilidades para a experiência. De um ponto de vista pragmático, embora com algumas reservas, pode tomar-se como referência a noção de W. James de que há interesse na elaboração filosófica da verdade quando esta permite uma orientação satisfatória entre diferentes momentos do fluxo da experiência ${ }^{17}$.

Admite-se, deste modo, a possibilidade de uma prestação de auxílio à orientação, por meio de uma procura de eficácia semântica, como sendo uma componente central do acompanhamento proporcionado pelo AF.

A consulta de AF consiste, assim, numa espécie de ensaio ${ }^{18}$ ou investigação conjunta sobre um tema que se tornou problemático para alguém, com vista a uma organização de ideias que permita maior clareza em relação à natureza e à dimensão desse(s) problema(s) e, concomitantemente, aumente quantitativa e qualitativamente o leque de hipóteses possíveis de compreensão e solução para os mesmos.

Mais precisamente, pode ser descrita como uma tematização da representação que alguém faz da situação em que se revê a si mesmo como diante de um problema por resolver, de questões que clamam resposta ou de uma exigência de decisão.

${ }^{17}$ Cf. William James, Idem ib., respectivamente, pp. 44, 46 e 48:

A. Se não se pode especificar nenhuma diferença prática então as alternativas têm na prática o mesmo sentido, e a disputa é ociosa. Sempre que uma disputa é séria devemos ser capazes de mostrar que alguma diferença prática é consequência da correcção de um ou outro lado.

B. A tarefa da filosofia deveria consistir inteiramente na descoberta das diferenças definidas que existirão para vós e para mim, em instantes definidos da nossa vida, se esta ou aquela formulação do mundo for a verdadeira.

C. (...) As ideias (que não passam de partes da nossa experiência) se tornam verdadeiras na medida em que nos ajudam a entrar numa relação satisfatória com outras partes da nossa experiência [em itálico no texto] para as resumir e viajar entre elas por atalhos conceptuais, em vez de seguir a interminável sucessão de fenómenos particulares. Qualquer ideia que nos possa transportar, por assim dizer, qualquer ideia que nos conduza proveitosamente de uma a outra parte da nossa experiência, ligando as coisas satisfatoriamente, trabalhando com segurança, simplificando e poupando trabalho, é verdadeira exactamente por isso, nessa medida, verdadeira instrumentalmente [termo em itálico no texto].

${ }^{18}$ Assim o caracterizou José Barrientos, 'Orientación Filosófica. El ensayo filosófico como modelo', 2006.; vide ainda, Jorge H. Dias e José Barrientos Rastrojo, Felicidad o Conocimiento? La Filosofía Aplicada como la Busquéda de la Felicidad e del Conocimiento (Sevilha: Doss Ediciones, 2009), p. 87 e ss. 
Em linguagem corrente, podemos afirmar que este é um trabalho que apenas se pode realizar na "primeira pessoa". Esta noção de que a "pessoa" que solicita a ajuda é o ponto de partida, o foco e o termo do trabalho de $\mathrm{AF}$, é recorrente na "literatura de AF", mas raramente são tidas em conta as dificuldades que levanta: não permite apreender claramente a diferença entre indivíduo, sujeito e pessoa, nem antever as tensões entre possibilidades práticas, narrativas de "si mesmo" e comunicações, sob cuja influência, todavia, o "consultante" elabora o seu pensamento e o comunica, e sobre as quais operará o trabalho dirigido pelo "conselheiro". Apesar de o tema não poder ser exaustivamente tratado por agora, devemos salvaguardar, no uso que lhe damos, que o significado da noção de "pessoa" é o de uma forma ${ }^{19}$ comunicativa e não de uma identidade individual dotada de subjectividade $^{20}$. Isto significa que nos confrontamos com uma unidade semântica referida à diferença entre consciência-percepção e comunicação e, por conseguinte, à diferença entre sistema e meio-ambiente, e não com uma unidade simples, transparente em relação a si mesma e em relação à sua participação discursiva no processo de comunicação.

Assim, desde que tendo-se em conta estas precauções, pode-se afirmar que o papel que o "conselheiro" desempenha consiste em assegurar que estão reunidas as melhores condições possíveis para que a pessoa possa organizar discursivamente o assunto que a traz à consulta e, de seguida, analise ela mesma, ainda que com a ajuda do "conselheiro", os esquemas mentais (crenças e valores) mediante os quais, em primeiro lugar, as situações que estão a ser tratadas surgiram no discurso como problemas.

Procuram-se reunir, portanto, condições necessárias a uma observação (e à possibilidade de comunicar sobre ela) tal que, em vez da própria experiência, passam a ser designados os moldes usados para dar forma à experiência; em que o observador ao qual um aspecto do "mundo" surgiu como problemático desvia por momentos o olhar dos dados do problema para reparar nas condições à luz das quais surge como esse problema.

A primeira dessas condições, contudo, é a de um reconhecimento dos limites insuperáveis de toda a observação. Na medida em que toda a observação consiste num evento em que necessariamente se co-diferenciam o observador e o observado, aquilo a que em Cibernética se chamou

19 Importamos o termo da Teoria da Forma de G. Spencer-Brown.

${ }^{20}$ As pessoas podem ser destinatários para a comunicação. (...) Podem servir como pontos de atribuição para as suposições causais e, em particular, para as responsabilidades. No entanto, tudo isso é exclusivamente realidade comunicativa sem nenhum efeito determinante nos processos da consciência. Cf. Niklas Luhmann, La Ciência de la Socie$d a d$, trad Silvia Pappe et al. (México: Universidad Iberoamericana, Instituto Tecnológico y de Estudios Superiores de Occidente e Editorial Antropos, 1996), p. 30. 
“observação de segundo grau", estando ela própria limitada pelo seu próprio ponto cego e não podendo observar-se a si mesma, nunca completa o sentido da experiência de observar a experiência ${ }^{21}$.

Deste modo, as "verdades" construídas na consulta não podem ser simplesmente pensadas a partir de uma concepção de realidade e mundo como universo ontologicamente constituído por entidades substanciais que se oferecem à representação pelo pensamento a partir da sua posição prévia, mas sim como determinações semânticas, como distinções ou selecções actualizadas pela diferenciação, intrínseca ao próprio processo de observação, entre observador e observado e entre forma do sentido e meio do sentido; em suma, como actualização da diferença entre actualidade e virtualidade.

Não obstante, é este mesmo limite que está na base da possibilidade do trabalho do AF. É apenas diante da impossibilidade de completar o processo de significação da experiência que se podem procurar na actividade filosófica novas perspectivas de orientação.

Mas é também esse limite que, permitindo desviar o olhar da experiência imediata para os modos da sua observação, permite ir além de uma perspectiva e de um modelo de trabalho de inspiração construtivista sem, todavia, permitir ao AF incorrer em novas versões da tradição essencialista.

$\mathrm{Na}$ verdade, o confronto com os esquemas próprios de observação do "mundo" impõe ao "mundo" uma nova figura, na qual é introduzida a diferença entre o indivíduo e o que o rodeia, e a qual se forma ao mesmo tempo que um novo ponto cego, o qual é o observador de segundo grau que precisaria ainda de uma outra nova observação para se incluir a si mesmo no campo do observado, e assim indefinidamente.

Deste ponto de vista, ao uso do termo indivíduo seria preferível a noção de um processo de diferenciação recíproca entre a entidade individual e o mundo, no qual deixa de ser possível localizar a ínfima espécie individual, quer se proceda por meio da percepção, do conhecimento por atribuição de notas ou da acção ${ }^{22}$, havendo, então, que abandonar a concepção tradicional de "mundo".

21 (...) A observação opera com a diferenciação por ela escolhida e (...) por isso mesmo não pode diferenciar-se a si mesma mediante outra diferenciação. Podemos dizer também que a observação utiliza a própria diferenciação como ponto cego. Apenas pode ver o que pode ver. Cf. Niklas Luhmann, Idem ib., p. 66. Uma importante consequência desta perspectiva (que, do nosso ponto de vista, tem um impacto decisivo no AF) é que: O observador das observações move-se, portanto, no nível no qual o mundo já só se pode ver como construção que resulta da constante observação de observações. Cf. Niklas Luhmann, Idem ib.,p. 76.

22 Edmundo Balsemão Pires, 'Ensaio sobre a Individualidade Prática', Revista Filosófica de Coimbra, 9 (2000), 351-433. 
Rejeitando o ponto de vista topográfico das substâncias ontologicamente dispostas ao longo das regiões da realidade, o próprio indivíduo surge como a unidade de uma diferença entre a sua unidade e a sua multiplicidade, entre a sua actualidade e a sua virtualidade, entre a necessidade e a contingência ${ }^{23}$.

Mas, como mostrou E. Balsemão Pires, a consideração do processo de individuação do ponto de vista prático obriga-nos a ir além da perspectiva construtivista, pois a este nível a individualidade não é o resultado de processos construtivos exteriores ao objecto individual, podendo a sua realidade, como algo que existe "fora da mente", ser atestada em certas experiências-limite interiores ${ }^{24}$.

Nestas, o carácter paradoxal do indivíduo é negativamente assinalado pela ameaça de uma ruptura da co-referência (ou por uma total coincidência) entre simplicidade e multiplicidade, isto é, pela iminência de uma dissolução irreversível da forma desse indivíduo.

Assim, o acesso à realidade do indivíduo impõe a construção do significado de uma unidade de uma diferença, e podem, então, captar-se as dificuldades que se colocam à orientação do indivíduo quando este se serve de arranjos semânticos que não têm em conta aquela forma.

Podem, então, as dificuldades que o individuo experiencia e relata ser perspectivadas como resultado de uma assimetria na pontuação da experiência individual, em termos das oposições actualidade-simplicidade e virtualidade-multiplicidade. Quanto mais esta assimetria se acentua para um dos lados e se torna o outro invisível (e incontrolado), quanto mais a co-referência destes dois lados do paradoxo em que se efectua a experiência concreta da individuação parece ameaçada de desagregação, maiores são as dificuldades que se lhe colocam. Muito esquematicamente: ao ser pontuada a actualidade, ganha força a possibilidade, quer como desejo de uma mudança tomada como impossível, quer como ameaça de mudança indesejada; se é pontuada a possibilidade, logo a força da actualidade se faz sentir, ou como resistência adversa ou como desejo de uma familiaridade que parece perdida.

Por consequência, o trabalho de construção de sentido realizado em AF não pode ser confundido com um processo de descoberta de uma verdade que se mantinha oculta e que o processo se encarregou de revelar. A base teórica do AF não consiste na afirmação de um vazio existencial ou de uma carência de sentido que seria preciso repor. O seu ponto de

${ }^{23}$ Cf. Edmundo Balsemão Pires, 'Metafísica e Construtivismo', em Método e Métodos do Pensamento Filosófico, ed Diogo Ferrer (Coimbra: 2007), pp. 201-228.

${ }^{24}$ Cf. Edmundo Balsemão Pires, "Ensaio sobre a Individualidade Prática", in op. cit., pp. 422-427. 
partida é, ao contrário, o de um excesso de sentido para o qual, segundo uma metodologia atenta às relações entre complexidade, contingência e selectividade, se procuram modos de redução que permitam o seu processamento funcional ao nível da consciência, ou, como sugeriremos à frente, se procuram estabilizar as condições de uma devolução do desassossego ao indivíduo.

Embora o desenvolvimento destas problemáticas não caiba dentro dos limites deste trabalho, a sua indicação deve assinalar já uma certa especificidade na orientação interpretativa que aqui se faz da noção vulgar de que o AF ajuda a ver um maior número de possibilidades de compreensão e acção. Se toda a construção de sentido impõe uma redução da complexidade, o que no $\mathrm{AF}$ se faz é procurar entre várias possibilidades selectivas de observação as que forneçam uma orientação mais satisfatória, independentemente de que, num determinado momento, a carga do "mundo" se abata com a mais pesada e desesperançada das actualidades ou com a mais estranha das indefinições.

A relação entre o problema experienciado e as condições que o determinam como tal torna-se, assim, o objecto central da investigação realizada na consulta, o que pode ser suficiente para uma alteração satisfatória do modo como a experiência em causa é significada e vivida pelo consultante.

Mas pode dar-se o caso de isso não suceder. Pode acontecer que o reconhecimento da necessidade de eliminação, da inutilidade ou das desvantagens de um determinado arranjo semântico não dissolva o carácter problemático da situação. Pode ser necessária uma reconstrução das ideias acerca do assunto a um outro nível. Nesse caso, compete ao "conselheiro" reorientar o ensaio com vista a que a pessoa possa testar a capacidade de encaixe de uma pluralidade de perspectivas diferentes sobre o assunto nas exigências de sentido que as suas capacidades de unificação da experiência lhe permitem actualizar nesse momento.

Isto não significa uma espécie de apresentação de um cardápio de ideias filosóficas de que o comensal deverá encomendar a que mais the convier, mas sim de uma estratégia (que pode ser posta em prática de muitas maneiras diferentes) que visa aumentar o número de hipóteses disponíveis e as capacidades de seleccionar conexões entre elas e, assim, proporcionar a construção de um significado mais rico e ao mesmo tempo mais útil para o problema que está a ser investigado (das relações entre o problema inicial - e/ou das extensões que se lhe vão acrescentando - e os esquemas mediante os quais é esse problema).

A metáfora do ensaio ajuda, assim, também, a reforçar que o papel do "conselheiro" não é, ao contrário do equívoco a que esta designação poderia conduzir, o de oferecer soluções, de expor respostas ou o de 
impor decisões, mas sim o de acompanhar o processo através do qual uma outra pessoa procura solucionar, responder ou decidir, aplicando-se a propiciar as melhores condições possíveis para o trabalho filosófico de procura de orientação e a fornecer uma variedade de meios típicos desse tipo de trabalho.

Diversas propostas quanto aos modos como esse acompanhamento se há-de concretizar têm sido, nos últimos anos, apresentadas por autores como Gerd Achenbach, Tim Lebon, Peter Raabe, Ran Lahav, Roxana Kreimer, Schlomit Schüster, J. Barrientos Rastrojo, ou Louis Marinoff, mas não pode falar-se de uma correspondência completa de pontos de vista $^{25}$, a não ser quanto a que o processo deverá privilegiar, quando não dar a exclusividade, ao uso de instrumentos, técnicas e métodos de análise filosóficos. Dito de outro modo: problemas filosóficos tratam-se filosoficamente. Havendo alguém que para o efeito julgue ser vantajoso procurar este tipo de ajuda especializada, poderá então contar com a figura do "conselheiro filosófico".

Este especialista é alguém capaz de conjugar uma sólida formação filosófica de base com competências comunicativas que lhe permitam aliar capacidades de escuta activa, de interpelação, de orientação de um diálogo argumentado, de transposição de conteúdos para um registo de linguagem acessível ao interlocutor e de esquematização, a conhecimentos sobre a História da Filosofia, sobre sistemas e escolas de pensamento, sobre núcleos de problemas e tradições conceptuais, sobre topoi argumentativos clássicos, com experiência no trato lógico do discurso e treinado na leitura, análise e comparação de diferentes perspectivas acerca de um mesmo assunto. Ao que se acrescenta, como vimos, para além do rigor, uma certa sensibilidade ao sofrimento do outro.

\section{Aproximação entre o AF e o ensino da Filosofia}

Tal apresentação não difere muito daquela que poderia referir-se a um professor de Filosofia do Secundário. Tal como neste último caso, a preparação do "conselheiro" não dispensa uma certa actualização de conhecimentos em outros domínios do saber. Noções básicas de Psicologia e Sociologia são exemplos de recursos muito importantes que devem estar disponíveis na prática docente como na prática do AF. Mas, tal como o ensino de Filosofia requer alguém que saiba Filosofia, a prática

${ }^{25}$ A apresentação e comentário destas propostas não têm lugar neste trabalho. Apenas a título indicativo, serão incluídas no final algumas referências bibliográficas que permitirão ao leitor interessado um trabalho de exploração inicial. 
do AF pressupõe a formação filosófica do "conselheiro", o que contraria certas afirmações mais ou menos recorrentes na "literatura de AF" de que qualquer pessoa, mesmo sem formação filosófica e sem conhecimentos acerca da História da Filosofia, pode exercer a profissão: o que sucederia nestes casos é que o desenvolvimento do trabalho quedaria muito limitado às circunstâncias em que a "filosofia de senso comum" funciona.

Esta proximidade, por um lado, e o facto de que o contacto formal com a Filosofia é, em geral, efectuado através da disciplina de Filosofia no Secundário, têm condicionado a recepção académica e popular do AF. Para as pessoas que não estão familiarizadas com ele, pensar em Filosofia é, geralmente, recordar as aulas de Filosofia, sendo muito frequente que, ao ouvirem pela primeira vez falar do AF, imaginem que se trata de uma espécie conferências ou de salas de estudo ou explicações.

Mas é possível que uma apresentação sumária da ideia geral de AF possa, de facto, tornar-se mais clara por meio de uma aproximação ao ensino. Vejamos alguns aspectos.

1. Uma das diferenças mais importantes diz respeito ao "programa". O professor deve seguir um determinado programa e, por mais que a sua actuação se centre no aluno, nunca deixa de estar condicionada por esse programa. Do ponto de vista do aluno, isto significa uma imposição de tópicos de estudo ao longo de um percurso que pode, obviamente, conduzir a um número indefinido de desvios em relação aos seus interesses, aos seus problemas, às suas inquietações. No caso do AF, o "programa" jamais é imposto ao consultante. São as suas questões ou problemas que definem os temas que serão tratados ao longo das sessões. Deles se parte e a eles se regressa em cada momento.

O papel do "conselheiro" não é, todavia, passivo, pois, deverá levar a cabo a escuta activa por meio da qual procurará identificar e destacar essas questões ou problemas a partir da narrativa que o consultante apresenta da sua experiência, bem como apontar outras questões ou problemas adjacentes ou de algum outro modo relacionados com aqueles que se destacam directamente do que o consultante relata, propor a discussão acerca da pertinência de relações já estabelecidas ou pressupostas no discurso, etc.

2. O calendário e o ritmo dos trabalhos, por seu turno, não se estipulam por decreto ministerial, mas sim de acordo com as necessidades ou os interesses do consultante. Não será também, portanto, o "conselheiro" a definir quando devem começar as sessões ou quando se chegou ao fim do tratamento de uma questão ou problema. Nem deverá ser ele, mas sim a pessoa que o procurou, 
a definir a frequência e o número de sessões, bem como os ritmos de trabalho, os períodos de revisão e de avanço ou a extensão e profundidade da investigação conjunta.

A capacidade de uma escuta activa é, de novo, quanto a estes aspectos, fundamental, uma vez que, apesar do que acaba de ser afirmado, cabe ao "conselheiro" perceber e, se necessário, ajudar a pessoa a tomar consciência das possibilidades e das exigências que se colocam em cada momento do processo de consulta. Cabe-lhe também a sensibilidade para discernir em que casos o AF não pode ser aplicado pelo risco de se tornar prejudicial.

3. Uma outra diferença importante diz respeito a avaliação do trabalho realizado. Tal como no caso da docência, também aqui este é um processo indispensável. Mas a diferença começa logo pela definição das metas e objectivos, visto que esta é realizada pelo consultante e não por um grupo ou conselho previamente constituído. É ele quem pode dizer o que o traz à consulta e que expectativas o animam. E quem pode referir-se aos resultados desejados e aos critérios segundo os quais o trabalho será apreciado como positivo ou negativo.

Uma vez mais, o papel do "conselheiro" não é aqui o de uma mera passividade. Em primeiro lugar, porque há metas e objectivos que não pertencem ao horizonte de aplicação do AF. Em segundo lugar, visto que o próprio arranjo inicial de objectivos e metas, na medida em que está necessariamente ligado aos esquemas de observação nos quais o problema se forma, acabará por ser tomado como elemento importante do tratamento que se seguirá, podendo ser submetido a escrutínio, questionado, revisitado, modificado. Assim, compete ao "conselheiro" o discernimento do grau de adequação entre as metas e objectivos que trazem uma pessoa à consulta $\mathrm{e}$ o tipo de trabalho que nela se pode realizar; e cabe-lhe também contribuir para uma apreciação e eventual modificação dos critérios segundo os quais foram traçados pelo consultante os respectivos objectivos, ou, pelo menos, para uma tematização da articulação entre esses critérios e aqueles esquemas mediante os quais a situação se tornou problemática.

A apreciação de cada etapa do processo de consulta deve ser apreciada à luz das metas e objectivos assim dinamicamente traçados. Para ambos os participantes no ensaio conjunto são fundamentais estes momentos de re-significação do processo que se está a desenvolver, não bastando avançar em frente como se fosse indiferente o efeito que o trabalho que está a ser realizado tem sobre o consultante.

Este aspecto aproxima e diferencia ao mesmo tempo o AF do ensino da Filosofia. A actual prática docente incorpora já este princípio sob a 
forma de uma avaliação formativa e existem também casos em que o aluno é quem define quando se sente preparado para se submeter a uma avaliação sumativa. Mas, mesmo nestes casos, a última palavra não deixa de ser do professor ou da equipa que avalia e define se houve sucesso ou insucesso.

No caso do AF, apenas o consultante pode asseverar se a consulta funcionou, se ajudou, se vale a pena prosseguir o trabalho, se se pode dar por concluído, ou se o melhor é abandoná-lo.

Apesar disso, evidentemente, o "conselheiro" mantém um importante papel ao introduzir no ensaio conjunto oportunidades de auto-observação que o consultante aproveitará para uma tomada de consciência e para uma organização discursiva dos efeitos do trabalho realizado sobre a qualidade da experiência.

4. Uma das perguntas com que se há-de contar quando se caracteriza genericamente o AF é: aprende-se Filosofia? É natural que assim seja, pois é indissociável da Filosofia o seu património de conteúdos, cujos momentos mais relevantes fazem, desde tempos muito remotos da sua História, parte dos planos de estudo filosóficos.

Podemos distinguir, para tentarmos responder a esta questão, entre métodos de trabalho típicos da Filosofia e conteúdos filosóficos. A utilidade da distinção, embora demasiado esquemática, consiste em que permite caracterizar um pouco melhor a consulta de AF. Nesta, aplicam-se métodos de trabalho típicos da Filosofia, mas não necessariamente sobre conteúdos filosóficos. Por exemplo, podem aplicar-se instrumentos de análise lógica, noções básicas de hermenêutica, podem realizar-se exercícios de argumentação, podem desenvolver-se actividades de esquematização de problemas, treinarse a construção de redes semânticas, etc. Mas não é obrigatório tomar como objecto de estudo os problemas clássicos da metafísica, da gnosiologia ou da ética; tampouco se impõe proceder à leitura de Aristóteles, Descartes ou Nietzsche.

Com efeito, tal como já acontece parcialmente na sala de aula, os conteúdos sobre os quais são aplicados métodos de trabalho filosóficos podem não pertencer ao plano da produção histórica de literatura filosófica. Isto acontece porque se considera que, em princípio, qualquer assunto pode ser tratado filosoficamente. Nisto não há novidade nenhuma - é, simplesmente, uma expressão do interesse tradicional da Filosofia pelo sentido da existência como um todo.

Tal como na sala de aula, a leitura de um poema, a apreciação de um quadro, a audição de uma composição musical, um filme, uma notícia de jornal ou uma simples opinião lançada por um aluno, podem servir de impulso para o trabalho filosófico, o mesmo acontece na 
consulta de AF. Neste contexto, esse impulso consiste no problema apresentado pela pessoa. É sobre esse conteúdo que começarão por se aplicar métodos de trabalho da Filosofia. Mediante esta aplicação, expectavelmente, alterar-se-á retroactivamente o próprio conteúdo inicial, o que poderá gerar um novo impulso filosofante. Até onde este processo pode chegar, depende dos casos e, sobretudo, das pessoas. Para algumas, uma aplicação básica de métodos de trabalho da Filosofia ao problema basta para diminuir a sua carga problemática e para produzir um nível de satisfação suficiente. Mas pode imaginar-se que, a partir de certa altura, sob uma exigência de aprofundamento, a consulta se pode tornar no lugar de uma verdadeira aprendizagem de conteúdos filosóficos, tornando-se possível e desejável a leitura de autores, comentadores, obras ou excertos que fornecerão novas possibilidades selectivas para a construção do sentido da experiência problemática.

Esta questão de saber se se aprende filosofia na consulta, para além de recorrente nos momentos de debate que é costume seguirem-se a apresentações sobre AF, tem sido também colocada por alguns autores, quase sempre com um intuito de publicitar este serviço apresentando-o como uma actividade agradável em que, ao contrário da experiência comum no Secundário, não há constrangimento de assiduidade, não há trabalhos de casa nem testes de avaliação, não há leituras obrigatórias, não há imposição de matérias aborrecidas. Tudo isto apenas parcialmente é aceitável, na medida em que é impossível antecipar o grau de exigência que a pessoa impõe a si mesma e ao próprio "conselheiro". Depois do que se disse quanto à centralidade do consultante no processo de consulta, seria contraditório afirmar agora que o AF não impõe trabalho exigente, nem assiduidade, nem tarefas realizadas em casa, nem testes, nem leituras - o mesmo se pode dizer em relação ao anúncio do AF como uma actividade aprazível. Com efeito, todos estes aspectos dependem da pessoa que solicita a consulta. Nada a pode impedir de se impor a si mesma tarefas árduas e mesmo desagradáveis, nada a impede de realizar os sacrifícios que entender para não ter que faltar a uma sessão, ninguém se lhe oporá se pretender ler obras de filósofos e ainda menos se a sua intenção é fazê-lo em casa.

$\mathrm{Na}$ medida em que se exercitam e aprendem algumas técnicas e métodos de trabalho filosófico nas sessões de AF, pode dizer-se que, a um nível básico, aí se aprende Filosofia. $\mathrm{O}$ facto de se poder introduzir o estudo de determinados temas ou autores apenas indica a possibilidade de que esta aprendizagem se possa prolongar e aprofundar indefinidamente.

Mas aprende-se Filosofia também no sentido em que, mesmo ao nível da mera aplicação de métodos e técnicas típicas do trabalho filosófico, se realizam 
sistemáticas "observações de segundo grau" que, não obstante os problemas de invisibilização que toda a observação comporta, permite a tomada de consciência quanto ao ter-se decidido assim proceder e quanto aos efeitos sobre o modo como o problema será tratado por causa dessa decisão.

\section{Aproximação entre AF e outras áreas de ajuda}

Com os seus cerca de trinta anos de idade, o AF não foi ainda capaz de determinar o seu lugar na Filosofia e na cultura em geral, nem foi capaz de se situar claramente face ao conjunto de outras actividades de "ajuda". $\mathrm{Na}$ base destas insuficiências tem estado a dificuldade de indicar a razão de ser do seu aparecimento nas sociedades contemporâneas desenvolvidas.

No entanto, esse é um requisito importante para a sua construção como para a obtenção de reconhecimento. Convém que se reflicta sobre o que está em causa para um determinado modo de organização da vida colectiva quando surge a noção de que cada indivíduo é responsável pela construção do significado da sua própria existência e de que para o ajudar nessa tarefa pode contratar o serviço de um profissional que se serve principalmente de métodos e conteúdos típicos da Filosofia. É imprescindível situar este aparecimento no contexto de um processo mais amplo que envolve transformações profundas ao nível da estrutura e do funcionamento da sociedade e que necessariamente repercute no nível da organização psíquica do "real".

Surgindo na sequência de uma longa tradição de "aconselhamento", o $\mathrm{AF}$ apresenta características que não conseguiríamos imaginar em épocas passadas mas que nos indicam algo sobre a especificidade de alguns dos problemas que hoje enfrentamos. Por outro lado, não sendo ele a única actividade de ajuda que podemos relacionar com estas transformações de fundo, impõe-se mostrar, para além do que o aproxima delas, aquilo que o distingue.

A pesquisa sobre AF deve incluir tópicos de reflexão sobre a sua relação com toda uma tradição de "aconselhamento" que envolveu filósofos desde a Antiguidade, intelectuais da modernidade, e os opinion makers e os experts da actualidade ${ }^{26}$; deve também confrontar-se com o aparecimento da gigantesca indústria de ajuda e bem-estar em que se incluem múltiplas e muito variadas disciplinas, práticas, serviços e mercadorias, que vão desde a Psicologia Clínica e da Medicina Psiquiátrica

26 Para um desenvolvimento do tema, cf. Edmundo Balsemão Pires, 'Ensaio de um programa de filosofia política', Revista Filosófica de Coimbra, 19 (2009), 259-296 (pp. em especial, as pp. 279 a 293). 
ao "counselling"a indivíduos e empresas, passando pelo "critical thinking", pela "programação neuro-linguística" e por muitas outras "ajudas", tais como as que mais visivelmente se baseiam em ecléticas misturas de esoterismos, holismos, transcendentalismos, misticismos, naturalismos, vitalismos, etc., todos eles, de alguma forma, dirigidos ao indivíduo ao qual propõem meios de orientação.

Estas diferentes incarnações da semântica contemporânea da ajuda (que não se esgota nos fenómenos atrás listados) permitem-nos pôr em causa que cada uma delas disponha da mesma capacidade de se reportar aos problemas gerados na sociedade actual e que efectivamente repercutem sobre a experiência individual. $\mathrm{O}$ simples facto de a comunicação actual poder tematizar algo como as actividades de ajuda privada e individual deve-nos chamar a atenção para a sua capacidade de incluir uma pluralidade de perspectivas irredutíveis acerca do sentido da vida e dos aspectos ético-morais da convivência humana. Isto não significa que, por causa disso, a cada perspectiva privada acerca da "realidade" tenha que ser atribuído o mesmo valor. Mas, muito pelo contrário, obriga a perguntar em que medida cada uma dessas perspectivas funciona - para a sociedade como sistema de comunicações; e para o indivíduo que sofre as constantes pressões do seu meio-ambiente social.

Aparentemente, a sociedade serve-se do fenómeno das actividades de ajuda como um dos mecanismos possíveis de reprodução de comunicações e, neste sentido muito lato, pode dizer-se que, do ponto de vista da sociedade, qualquer uma delas funciona. Este aspecto mereceria ser averiguado, visto que está em causa uma conjugação entre aumento de dependências ou forças sociais centrípetas e independências ou forças sociais centrífugas. A respeito, pelo menos duas perguntas se colocam: como é que a comunicação prossegue apesar da liberdade? Como é que a liberdade se produz apesar da comunicação?

Embora não desenvolvamos o tema neste estudo, podemos reportar-nos aos contributos da teoria dos sistemas sociais de N. Luhmann para a compreensão de que a diferenciação evolutiva entre sistema da consciência (acção-percepção) e sistema da sociedade (como sistema de todas as comunicações), posicionando-os um em relação ao outro como sistema e meio ambiente e direccionando-se para uma crescente autonomia operativa do sistema em relação ao seu meio, permite também diferenciar dois pontos de vista diferentes: o da comunicação e o do indivíduo. Do ponto de vista da comunicação, esta evolução significa o aumento das possibilidades de comunicar; do ponto de vista do indivíduo, uma maior liberdade ${ }^{27}$.

${ }^{27}$ Para um desenvolvimento dos problemas lógicos que resultam desta necessidade de partir de uma pluralidade de "centros de reflexão", cf. G. Günther, 'Cybernetic Ontology and Transjunctional Operations’, em Self-Organizing Systems, ed M. C. Yovits, G. T. Jacobi 
A relativa indiferença recíproca entre reprodução do sentido no meio da comunicação e reprodução do sentido no meio da consciência é uma das teses mais controversas de N. Luhmann, mas apresenta grande valor para o AF, convidando a pôr em causa as teses que vêem no aparecimento desta área uma resposta a uma sociedade carente de sentido, e a trabalhar a partir da premissa de que nas relações que uma sociedade complexa forma com o seu meio ambiente o que está em causa são diferenças sistémicas temporalizadas entre operações de produção e conexão de sentido.

O problema deixa, então, de poder ser perspectivado ao nível de uma insuficiência de produção de sentido no indivíduo ou na sociedade constituída por indivíduos, e passa a ter que se considerar o ponto de vista de um excesso incontrolável (ou apenas auto-regulado) de sentido no meio da comunicação e das dificuldades de sincronização entre a reprodução do sentido a esse nível e a que se dá ao nível do sistema psíquico, concebido como meio ambiente do sistema da sociedade 28 .

Segundo este ponto de vista, é banal afirmar que o facto de a sociedade poder incluir comunicações tematizadas como actividades de ajuda, não significa de todo que em cada proposta de ajuda esteja disponível, para todos os casos, uma orientação eficaz do indivíduo no mundo.

Mas esse objectivo é central para o AF, o que exige que na sua construção prática e metodológica esteja subjacente e seja actuante uma base teórica efectivamente capaz de proporcionar as observações e as descrições que a complexidade do sistema da sociedade exige a quem precisa de se orientar.

\section{Especificidade e limite do AF: indicação do "desassossego", oportunidades selectivas e orientação}

O trabalho na consulta de AF não deve ser visto como uma organização discursiva do pensamento considerado como algo substancialmente isolado ainda que situado diante do mundo e com uma capacidade mais ou menos desenvolvida de o representar objectivamente. Se se reconhecer no "mundo" um resultado em permanente actualização dessa organização e

\footnotetext{
e G. D. Goldstein (Washington D. C.: Spartan Books, 1962), pp. 313-392 < http://www. vordenker.de/ggphilosophy/gg cyb ontology.pdf> (16 de Julho de 10).

${ }^{28}$ Os homens, as distintas pessoas individuais, participam de todos estes sistemas sociais, mas não se incorporam de todo em nenhum destes sistemas nem na sociedade global. A sociedade não se compõem de seres humanos, compõe-se de comunicações entre homens. Niklas Luhmann, Teoría politica en el Estado de Bienestar (Madrid: Alianza Editorial, 2002), p. 42.
} 
se se reconhecer nessa organização um modo de diferenciação do próprio "mundo", a noção de "experiência" designa necessariamente a dupla forma de uma indicação da unidade da distinção entre "mundo" e organização semântica.

Ainda que toda a experiência seja apenas dada na interioridade e na opacidade de uma mente individual capaz de auto-reflexão, cada um dos seus momentos pressupõe uma abertura a um meio-ambiente carregado de acontecimentos de natureza distinta. Seja qual for a maneira como essas duas ordens de eventos se relacionam e seja o que for necessário para se poder observar as coisas desta maneira, a verdade é que mesmo a mais alucinada elaboração mental integrará referências a um "mundo exterior" com o qual o lado "interior" da experiência mantém permanentes relações. A alteridade, digamos, é então, apenas a outra face da experiência própria.

Este é um modo possível de aproximação ao núcleo justificativo e à possibilidade do próprio $\mathrm{AF}$, oferecendo uma noção diferencial de experiência que se propaga ao longo de indefinidos níveis, até chegar a atingir o próprio, a identidade, o "eu". Tendo-a em consideração, pode afirmar-se que a orientação eficaz apenas por acaso será aquela que se constitui como orientação no mundo de uma realidade pensada como individual-subjectiva e pressuposta como simples, una, separada e completamente definida em relação a tudo o resto. A função pragmática do AF obriga a ter em linha de conta que o estatuto ontológico do indivíduo impõe tomá-lo como actualização temporalizada de possibilidades, como mútua implicação entre simplicidade e multiplicidade e entre necessidade e contingência.

Uma base teórica funcional deverá permitir, portanto, em primeiro lugar, tratar o indivíduo como a unidade de uma diferença ineliminável entre aquilo que lhe confere unidade e identidade e aquilo que o resguarda dessa determinação de cada vez que ele pretende observar-se a si mesmo como essa unidade e identidade. Por outras palavras: deverá fornecer ao AF a capacidade de recorrer à forma do indivíduo para ajudá-lo a orientar-se.

Deste modo, o AF não poderá partir de ideias acerca do "mundo" e acerca do "eu", mas de modos de observação do "mundo" e do "eu". Não podendo evitar os paradoxos da co-referência entre observador e observado e simplicidade e multiplicidade do indivíduo prático, não poderá proceder como se fosse possível reportar-se a uma separação plena entre os dois termos dos pares de opostos, ora pretendendo a existência de uma realidade independente do sujeito (um "mundo exterior" e um "eu" que se me impõem) que por ela é pressionado e que se lhe deve adaptar, ora pretendendo que ao sujeito basta adoptar novas ideias para que a realidade the seja conforme. 
Com efeito, em cada momento da nossa experiência, o "eu" impõe-se-nos tal como se nos impõe o "mundo". Nem um nem outro são mais "relativos" pelo simples facto de poderem ser apontados como uma construção que se realiza por meio da consciência individual. A noção de uma orientação eficaz e satisfatória não significa, pois, uma capacidade de pintar o "mundo" e o "eu" em tons agradáveis e apaziguadores, nem, pelo contrário, como acontece com muitas outras actividades de ajuda, em matizes de um fatalismo que apesar de tudo é capaz de imprimir uma certa simplicidade e familiaridade ao "mundo" e ao "eu". A dureza da "realidade" impõe-se em cada momento da construção da experiência e essa é a única razão para que nos procuremos orientar por meio de um regresso à análise das nossas crenças e valores. É apenas quando as nossas crenças e valores nos tornam demasiado vulneráveis em relação à calosidade do meio que sentimos necessidade de os rever - e se o fazemos, é com esperança de assim amaciarmos a experiência.

Ao actuarmos sobre as nossas crenças e valores podemos pretender tornar menos áspera a nossa experiência. Como vimos, há muitas maneiras de o fazer. Uma delas consiste na anestesia química do impulso para a reflexão. Sabemos que muitos casos de angústia, melancolia, tristeza ou frustração são hoje assim tratados. Podemos, também, socorrer-nos de uma grelha de leitura que nos permita interpretar os nossos comportamentos e emoções como traduções (ou mesmo traições) de funções biológicas inconscientes ou de desvios do normal processo de construção da personalidade e da identidade - o que de algum modo nos justifica e significa. Podemos interpretar o mundo religiosamente, depositando a nossa fé numa ordem superior e transcendente que dá uma finalidade valiosa a tudo o que acontece. Podemos abraçar a ideia de um progresso histórico-social de que somos agentes para quem todo o mal que possa acontecer tem ainda um sentido último. Desde que qualquer uma destas alternativas funcione, podemos acolhê-la como legítima e desejável.

$\mathrm{O}$ rigor sensivel que caracteriza o AF pode também servir o intuito do alívio, da consolação, do apaziguamento, da familiarização, etc. Essa é, como vimos, a sua grande aposta. No entanto, o trabalho que desenvolve não se fixa na construção de um sentido em falta, mas sim numa radicalização da questão do sentido da vida, do mundo, da experiência, radicalização essa que avança da observação para a observação da observação e do problema do sentido para o problema do sentido do sentido.

Não se pode esquecer que nem mesmo quando na sua História a Filosofia admitiu a entrada das mais belas e optimistas arquitecturas mentais acerca da constituição ou dos planos últimos da realidade, nunca o espanto, a inquietação, a perturbação, o desassossego, a incerteza, a estranheza, estiveram completamente ausentes. Nem mesmo quando recorremos aos 
mais sofisticados apetrechos da nossa mente racional para nos defendermos do "real", obtemos tréguas por parte da sua dureza e da sua estranheza. Disso nos dá quase sempre conta o trabalho filosófico e disso nos deve também dar conta o trabalho realizado no AF. Por maior e mais prolongado que seja o consolo que nos traga a ajuda, não estamos livres da pressão do "real", dos seus confrontos, das suas desautorizações, das suas imposições e das suas recusas. Movemo-nos na mais plena inquietação ou, como diria Bernardo Soares, no seio do desassossego.

Não pretendemos, com esta afirmação, regressar a uma análise existencial. Mantemos o princípio construtivista de que não há observação sem indicação ou pontuação. Assim, a noção de "desassossego" não nos pode servir para designar um traço ontológico específico da "natureza humana". O que nos permite é dar conta da pluralidade de posições de observação possíveis e das necessidades de movimentos de oscilação entre elas, como entre figura e fundo, quando aspiramos a uma síntese unificadora do sentido da "realidade", de um "ente", de uma "experiência" ou de uma "situação". Não tanto, todavia, no sentido de um desconforto psíquico originado pela impossibilidade de uma coincidência plena entre actualidade e possibilidade, ou entre necessidade e liberdade práticas, não no sentido de uma metafísica "condenação à liberdade", mas antes no sentido contrário da ameaça sempre latente de precipitação do actual sobre o virtual e do virtual sobre o actual, isto é, da ameaça de dissolução da individualidade sofrida ao nível de uma experiência interior.

No entanto, esta espécie de "desassossego do desassossego" parece ser o que oferece ao AF a sua possibilidade. É ele o motor implícito de todas as grandes simplificações semânticas por meio das quais se procura uma cristalização psíquica do sentimento de segurança ou familiaridade do actual (incluindo, em geral, as orientações mais "revolucionárias"). Em certos casos, o efeito deste impulso visando a simplicidade acaba por dificultar a consideração da multiplicidade, e a visão do que é pode, então, sobrepor-se como realidade fatal e inexorável sobre tudo o resto, atingindo, portanto, o resultado oposto ao pretendido.

Este excesso de possibilidades é o que, de uma forma geral, subjaz a todo o impulso filosófico e nos faz habitualmente associá-lo a um sentimento de inquietação. Mas, como se vê, o desconforto pode também surgir de viés, como resultado de uma construção de sentido demasiadamente centrada num determinado aspecto ou num determinado arranjo semântico da experiência, o qual é incapaz de integrar a consideração desse excesso e, portanto, cego e impotente em relação ao mesmo. Incapaz de orientar, apenas pode forçar o desgaste que resulta do efeito de fricção entre a "filosofia pessoal de vida" de alguém e a desmesura contida nas suas possibilidades de experiência. 
Se a ajuda de filosófica funciona, é porque nos permite compreender a mobilidade do "real" e a pluralidade das suas simultâneas e actuais configurações; permite-nos compreender que na actualidade daquilo a que se chama "realidade" estão inscritas múltiplas possibilidades de observação e de construção de sentido; permite-nos dar conta da pluralidade de centros em que a realidade se auto-reflecte; permite-nos observar o modo como outros centros de reflexão a observam; permite-nos apreender os processos por meio dos quais cada um deles aprende a manter a sua autonomia apesar das recíprocas perturbações de uns sobre os outros; permite-nos entender que uma parte da dureza da experiência resulta da demasiada rigidez que lhe impõem as nossas crenças e valores ou da estreiteza das nossas assumpções; permite-nos duvidar acerca da possibilidade de uma correspondência entre uma visão simples e fixa do mundo e os factos concretos e complexos dessa experiência; e permite-nos lançar alguma luz sobre o facto de nem podermos aceitar as reduções relativistas e subjectivistas que fariam de nós pequenos deuses criadores do nosso próprio mundo, nem aquelas que nos reduzem a escravos das circunstâncias.

Esta ajuda é, portanto, o contrário de um apaziguamento por meio de uma qualquer estratégia de invisibilização da excessividade da experiência, o que levanta o problema de saber, afinal, em que tipo de alívio, consolação ou apaziguamento se pode apostar quando se aposta no AF.

A resposta está na própria consideração do mencionado excesso, pois, se de excesso se trata, algo que está em demasia impõe selectividade. Todo o acto de significação a pressupõe (à selectividade), e a construção filosófica não é excepção. O que, porém, a especifica é a sua intenção indicativa, no sentido em que não se limita a discorrer sobre o que é indicado (o seleccionado pela observação), mas procura indicar a indicação do indicado (o próprio seleccionar). Assim, a aposta a que se refere a sugestão de que filosofar pode ajudar baseia-se nas oportunidades que poderão tornar-se visíveis quando alguém se investe no trabalho de investigar se as selecções a partir das quais observa e significa a sua experiência são as únicas possíveis ou as mais funcionais. Trata-se de um trabalho de modalização de esquemas de pensamento e de apreciação demasiado categóricos, que tanto opõe resistência à ameaça de dispersão das sínteses significativas do "mundo" sob a pressão do seu duplo simétrico e virtual de possibilidades por realizar (que se constitui no mesmo tempo em que se actualizam tais sínteses), como contraria o efeito de "afunilamento" perceptivo e emocional em que se arrisca a enredar-se aquele que se debate com a urgência da melancolia, com a tristeza, a frustração, a angústia, o desespero, os quais lhe parecem advir de uma realidade que apenas conhece a necessidade do ser. 
Pode, por consequência, acrescentar-se à ideia geral de AF a nota de uma prática que, ajudando a indicar o carácter desassossegado do "mundo", aposta com isso poder prestar um auxílio, o qual consiste, até certo ponto, numa devolução do desassossego ao indivíduo, mediante a qual se abrem novas possibilidades selectivas de redução da complexidade a formas de sentido capazes de proporcionar orientação.

\section{REFERÊNCIAS BIBLIOGRÁFICAS}

A. PhILliPs Griffiths, ed., Philosophy, Psychology and Psychiatry (Cambridge: Press Syndicate of the University of Cambridge, 1994).

EDMundo Balsemão Pires, A Sociedade sem Centro - Diferenciação funcional e unidade política da sociedade. A partir da obra N. Luhmann (Portugal: Autonomia 27, 2004).

, 'Diferenciação funcional e unidade política da sociedade. A partir da obra de N. Luhmann.', Revista Filosófica de Coimbra, 12 (2003), 69-155.

, 'Ensaio de um programa de filosofia política', Revista Filosófica de Coimbra, 19 (2009), 259-296.

, 'Ensaio sobre a Individualidade Prática', Revista Filosófica de Coimbra, 9 (2000), 351-433.

'Metafísica e Construtivismo', em Método e Métodos do Pensamento Filosófico, ed Diogo Ferrer (Coimbra: 2007), pp. 201-228.

FionA Jenkins, 'Care of the Self or Cult of the Self?: How Philosophical Counseling gets Political', International Journal of Philosophical Practice, 1 (2001) <http://www.aspcp.org/ijpp/jenkins.pdf> [acedido 16 Abril 2010].

G. GÜNTHER, 'Cybernetic Ontology and Transjunctional Operations', em Self-Organizing Systems, ed M. C. Yovits, G. T. Jacobi e G. D. Goldstein (Washington D. C.: Spartan Books, 1962), pp. 313-392<http://www.vordenker. de/ggphilosophy/gg_cyb_ontology.pdf>.

GERD Achenbach, 'A short answer to the question: What is Philophical Practice?' $<$ http://www.igpp.org/eng/philopractice.asp > [acedido 16 Julho 2010].

Gustavo Bueno, El mito de la felicidad - Autoayuda para desengaño de quienes buscan ser felices (Barcelona: Ediciones B, 2005).

Jorge H. Dias, e José Barrientos Rastrojo, Felicidad o Conocimiento? La Filosofía Aplicada como la Busquéda de la Felicidad e del Conocimiento (Sevilha: Doss Ediciones, 2009).

José Barrientos, Introdución al Asesoramiento y la Orientación Filosófica (Tenerife: Ediciones Idea, 2005).

'Orientación Filosófica. El ensayo filosófico como modelo', 2006.

KWB Fulford, e Giovanni Stanghellini, 'Dialogues in Philosophy, Mental and 
Neuro Sciences', 2009 <http://www.crossingdialogues.com/fulford.htm>.

LARA Sayão Ferraz, 'A necessidade de Exercer o que é Próprio do Homem', em Encontros Portugueses de Filosofia Aplicada, ed Jorge H. Dias (Albufeira: APAEF, 2008), pp. 17-27.

Lou Marinoff, As Grandes Questões da Vida (Lisboa: Editorial Presença, 2005).

Mais Platão, Menos Prozac (Lisboa: Editorial Presença, 2001).

, Philosophical Practice (Nova Iorque: Academia Press, 2002).

Luís António Umbelino, 'Maine de Biran e a Société Médicale e Bergerac: contributos para uma história da ideia de saúde', em Corpo, Saúde e Espaço Público, Cadernos do LIF, n. 22 (Coimbra: Ariadne Editora, 2006), II, 25-37.

LydiA B. Amir, 'Three Questionable Assumptions of Philosophical Counseling', International Journal of Philosophical Practice, 2 (2004), 2-32.

MARIA José Cantista (Coord.), A Dor e o Sofrimento - Abordagens (Porto: Campo das Letras, 2001).

MARIA Luísa Portocarrero, Daniel Serrão, e Luís António Umbelino, Corpo Saúde e Espaço Público, Cadernos do LIF, n. ${ }^{\circ} 2$ (Coimbra: Ariadne Editora).

MARLi A. Pechula, 'A Filosofia e seus usos: crítica e acomodação' (Brasil: Estadual de Campinas, 2007) <http://www.diaadiaeducacao.pr.gov.br/diaadia/ diadia/arquivos/File/conteudo/artigos_teses/FILOSOFIA/Teses/Pechula.pdf $>$ [acedido 12 Abril 2010].

N. POLlastri, 'Breve storia della consulenza filosófica', em Un introduzione al philosophical counseling (Catanzaro: Rubettino Editore, 2003).

NiKLAS Luhmann, A improbabilidade da comunicação, $4 .^{\circ}$ ed (Lisboa: Vega, 2006).

, Complejidad y modernidad - de la unidad a la diferencia (Madrid: Editorial Trotta, 1998).

, La Ciência de la Sociedad, trad Silvia Pappe, Brunhile Erker, Luis Felipe Segura e Javier Torres Nafarrate (México: Universidad Iberoamericana, Instituto Tecnológico y de Estudios Superiores de Occidente e Editorial Antropos, 1996).

, Teoría política en el Estado de Bienestar (Madrid: Alianza Editorial, 2002).

Org.: Adelino Cardoso e M. ${ }^{a}$ L. ${ }^{a}$ Ribeiro Ferreira, e R. Descartes, Medicina dos Afectos - Correspondência entre Descartes e a Princesa Elisabeth da Boémia (Oeiras: Celta Editora, 2001).

P. RaABe, Philosophical Counselling. Theory and Practice (Londres: Praeguer Publisher, 2000).

PAUL Watzlawick, A realidade é real?, trad Maria Vasconcelos Moreira (Lisboa: Relógio d'Água, 1991).

R. LAHAV, e Y. Tillmanns, Essays on Philosophical Counselling (Nova Iorque: University Press of America, 1995). 
S. C. Schuster, Philosophy Practice. An Alternative to Counselling and Psychoterapy (Westport (Connecticut): Praeguer Publisher, 1999).

Tim LeBon, Wise Therapy. Philosophy for counsellors (Londres: Continuum, 2001).

VVAA, Actas do I Encontro Português de Filosofia Prática - 2005, ed J. Humberto Dias (Lisboa: APAEF, 2006).

, Encontros Portugueses de Filosofia Aplicada, ed J. Humberto Dias (Albufeira: APAEF, 2008).

WILLIAM JAMES, O Pragmatismo - um nome novo para algumas formas antigas de pensar (Lisboa: Imprensa Nacional Casa da Moeda, 1997). 